\title{
A Quest for Poison Trees in Indian Literature, Along with Notes on Some Plants and Animals of the Kauṭilīya Arthaśāstra
}

Ronald E. Emmerick in memoriam piam

\section{Poison Trees - An Introduction}

The materia medica of Indian medicine is usually characterized as extremely rich. The number of drugs employed is very large and varied indeed. Yet, the pharmacopoeia of classical Āyurveda is restricted. Substances known in Vedic times are absent. The most famous example of these is soma. ${ }^{1}$ Numerous plants used in tribal medicine have not been incorporated. Moreover, the commentators on the early texts explicitly declare that they are no longer familiar with the identity of several notorious plants, such as those composing the octad designated as the astavarga which consists of eight ingredients of important compound medicines. When these commentators are at a loss with regard to the identities of plants or animals, they sometimes refer to tribes, mostly the Kirātas and Śabaras, as still possessing the relevant knowledge and to be consulted on the matter. Examples are the poisonous substances listed in the Carakasaṃhitā (Ca.) and Suśrutasaṃhitā (Su.). ${ }^{2}$

Striking by their apparent absence from early Indian literature in general are two trees that produce extremely potent poisonous substances, which are much employed by hunters in South and Southeast Asia. Their names are Strychnos nux-vomica Linn. and Antiaris toxicaria (Pers.) Lesch.

The initial part of this paper will mainly be devoted to the first of these trees.

1 soma is only mentioned in chapter 29 of the Cikitsāsthāna (Ci.) of the Suśrutasaṃhitā and in the Kāśsyapasaṃitā, in a prescription for a fumigation with soma as one of the ingredients (Kalpasthāna [Ka.] 1.11f.). Suśruta's soma is not related to the Vedic plant of that name.

2 See Cakrapāṇidatta ad Ca. Ci. 23.11-13 and Ḍalhaṇa ad Su. Ka. 2.5. Compare also Su. Sūtrasthāna (Sū.) 36.10 with the comments by Ḍalhạa. 
Strychnos nux-vomica Linn.

Strychnos nux-vomica Linn., the strychnine tree, belongs to the family of the Loganiaceae. The large genus Strychnos Linn., widespread throughout the tropics and subtropics, has nearly twenty representatives in India, some of which are used for medicinal purposes.

The strychnine tree is common in forests of the warmer parts of India and in those of Sri Lanka and Myanmar. In India it occurs from Bihar and West Bengal to all the more southern regions where it grows up to an altitude of about 1,200 metres (4,000 feet). The tree is evergreen in moist ecosystems, but in dry areas it may shed its leaves for a short time. It is medium-sized and can attain a height of fifteen to twenty metres. The trunk is fairly straight. The leaves are opposite, short-stalked, smooth on both sides, and oval in shape, eight to fifteen $\mathrm{cm}$. long and broadly elliptic. The flowers are small, greenish white, in terminal compound cymes. The fruits are globose berries, 2.5 to $5 \mathrm{~cm}$. in diameter, with a smooth hard shell of a beautiful orange to orange-brown colour when ripe. They are filled with a gelatinous pulp in which the seeds are immersed. These seeds are disc-shaped, about 20 to $25 \mathrm{~mm}$. in diameter and $4 \mathrm{~mm}$. thick, slightly depressed on one side and with a prominent, elevated umbilicus on the other; they are hard and leathery, ash- or greenish grey, and covered with numerous shining silky hairs. They are inodorous, but exceedingly bitter.

The seeds, called nux vomica or emetic nut, are very poisonous through the presence of the strongly toxic alkaloids strychnine and brucine, in addition to other minor alkaloidal constituents. These alkaloids occur not only in the seeds but also in the roots, bark and leaves, and, to a minor extent, in the fruit-pulp and fruit-shells.

The seeds are an effective poison for animals and also useful as an insecticide. Many tribals use them in the preparation of arrow- and dartpoisons.

This last point is remarkable and leads to the question whether these seeds and their toxicity have been known in India since early times. It seems improbable that hunters were unacquainted with their usefulness in killing game and that this knowledge was not transmitted to other layers of the community. References to arrows besmeared with a poisonous substance are far from rare in Sanskrit literature.

These visadigdha arrows and other weapons attest to the knowledge of suitable poisons. One of these may have consisted of a substance made with the seeds of Strychnos nux-vomica. Even more effective is Antiaris 
toxicaria (Pers.) Lesch. Its latex is extremely toxic due to the presence of myocardial poisons, called cardenolides, and is well known as an arrow-poison in Southeast Asia, where the tree from which it is derived is called the upas. Its advantage is that the quarry can be consumed without any danger. ${ }^{3}$

\section{Antiaris toxicaria (Pers.) Lesch.}

Antiaris toxicaria, belonging to the small genus Antiaris, distributed over tropical Asia, of the family of the Moraceae, is a huge monoecious tree, reaching a height of up to 76 metres, and occurs in the Western Ghats, on the Andaman Islands, in Sri Lanka and in Myanmar. It is also found in Malaysia and Indonesia. The bark is smooth; the leaves are 10 to $20 \mathrm{~cm}$. long, oblong and glossy. The male flowers are crowded on the surface of an orbicular, axillary receptacle, but the female flowers are solitary. The purple fruits resemble small figs and are intensely bitter when young; ripe fruits are reported to be edible. The latex exuding from the pierced trunk is pale yellow when fresh, later becoming dark brown and extremely bitter. In South India, where the plant is frequently met with, the poisonous property of the milky juice seems to be hardly known. The bark, however, when soaked in water and beaten, is suitable for making clothes. Formerly, the tree was well known as the "sacking tree", the felted inner bark being extensively used for making sacks of excellent quality. ${ }^{4}$

Strangely enough, both trees seem to be completely absent from early Sanskrit literature.

The Appearance of Strychnos nux-vomica in Sanskrit Literature

The secondary literature on Strychnos nux-vomica is intriguing since several important sources assert straight out that it appears late in the texts.

3 On arrow-poisons and on the Strychnos species, see the publications of N.G. Bisset listed in my "An Annotated Bibliography of Indian Medicine". Search the same website for Antiaris toxicaria, the upas or poison tree.

4 See Dymock et al. 1890-1893: III/348-355; Watt 1885-1893: I/268. On the medicinal uses of Antiaris toxicaria, see Muthulakshmi 2004. 
The original source of this claim has still to be discovered. The earliest author to make the claim I could find is Udoy Chand Dutt in the 1877 edition of his The Materia Medica of the Hindus. He remarks: ${ }^{5}$

Nux vomica has been introduced into Hindu medicine at a recent period. There is no generally recognized Sanskrit name for it. In some recent Sanskrit compilations it is mentioned under its vernacular name kucilā, a term which is not to be found in standard Sanskrit dictionaries. Sārangadhara and other writers give some prescriptions containing a drug named visamusti, which is generally interpreted to mean in these places nux vomica seeds; but vișamuști according to the Bhāvaprakāsáa has an edible fruit and is called kareruā in Hindi. In this work the Sanskrit term kupilu and its synonyms, kulaka, vișatinduka, markatatinduka, etc., are said to be the Sanskrit names for kucila and this translation is followed in some Hindi medical books, as for example in the treatise on the properties of drugs, compiled by Paṇdit Keśava Prasāda Dvivedī of the Agra College. This interpretation however is not accepted in Bengal, for neither Wilson nor Sir Rājā Rādhākānta Deva has given kucilā as the vernacular for kupilu, nor does this term or any of its synonyms above mentioned, occur in any Sanskrit medical prescription. In our account of this drug we will according to the practice of our kavirājas in Bengal interpret vișamusti i as kucilā.

U.Ch. Dutt adds an important remark, quoted by later authors. He says:

Nux vomica seeds produce a sort of intoxication, for which they are habitually taken by some natives as an aphrodisiac. Those who do so gradually become so far accustomed to this poison that they often come to take one seed daily, which is cut into small pieces and chewed with a packet of betel leaf.

R.N. Chopra, R.L. Badhwar and S. Ghosh ${ }^{6}$ add that the powdered seeds mixed with food are also largely given as a tonic to horses; feeding upon the leaves imparts a bitterish taste (characteristic of strychnine) to the milk of cows, and the people of localities where this is a custom, attribute good digestibility and tonic properties to such milk, and not without reason.

\section{Flückiger and Hanbury write in their Pharmacographia: ${ }^{7}$}

Nux vomica, which was unknown to the ancients, is thought to have been introduced into medicine by the Arabians. But the notices in their writings which have been supposed to refer to it, are far from clear and satisfactory. We have no evidence moreover that it was used in India at an

\footnotetext{
5 Dutt 1877: 198; the same text is found in the revised edition (Dutt 1922: 199).

${ }_{6}$ Chopra et al. 1940: 699.

7 Flückiger - Hanbury 1879: 384.
} 
early period. Garcia d'Orta, an observer thoroughly acquainted with the drugs of the west coast of India in the middle of the 16 th century, is entirely silent as to nux vomica. Fleming, writing at the beginning of the present century, remarks that nux vomica is seldom, if ever, employed in medicine by the Hindus, but this statement does not hold good now.

The Fleming referred to is John Fleming, the author of "A Catalogue of Indian Medicinal Plants and Drugs, with their Names in the Hindustani and Sanscrit Languages", published in Calcutta in 1812 as part of the Asiatic Researches. ${ }^{8}$

In the year 1893, both George Watt and C.D. Maclean discussed nux vomica. Watt ${ }^{9}$ takes much from U.Ch. Dutt, but qualifies the latter's statement that the drug does not appear to have been used in early Sanskrit medicine by remarking that it is quite possible that some part of the tree may have been used by the aboriginal tribes of India from a very early date, since nowadays we find the wood used as a common tonic over very extensive tracts of country. He also says that the $\mathrm{Mu}$ hammadans' knowledge of the uses of nux vomica seems to have been derived from the Hindus, as Makhzan-el-Adwiya concludes his description of the drug by saying that much information will be found about the drug in Hindu works. Maclean ${ }^{10}$ only remarks that the seeds were first introduced into medicine by the Arabs and that they have not been described by Sanskrit writers.

The assertion that Strychnos nux-vomica appears late in Sanskrit texts seems to have become a cliché in the secondary literature. Even P.V.

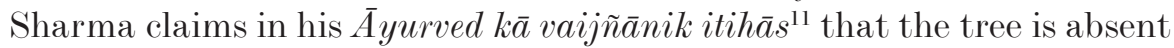
from the Brhattray $\overline{1}^{12}$ and that its introduction into medicine must therefore be of a later date. He supposes that its use has been promoted by the alchemists (rasācāryas).

This claim by an expert like P.V. Sharma is surprising. Actually, the state of affairs in the question we are investigating is different.

8 Asiatic Researches 11 (1812) 153-196.

9 Watt 1885-1893: VI.3/380.

10 Maclean 1893: 690.

11 Sharma 1975a: 342.

12 The Bṛhattraȳ consists of the Carakasaṃhitā, the Suśrutasaṃhitā and the Aștāñ gahṛdayasaṃhitā. 


\section{The Evidence of the Medical Treatises}

Perusal of the literature reveals that various Indian scholars have suggested that Strychnos nux-vomica may be referred to in the Carakasampitā. Even K.C. Chunekar, who collaborated with P.V. Sharma as a lecturer at the Department of Dravyaguna of the Institute of Medical Sciences of Banaras Hindu University, did so in the Glossary of Vegetable Drugs in Bṛhattraȳ, which he wrote together with Thakur Balwant Singh.

In regard to a controversial drug, called $k \bar{a} k \bar{a} n d a$, mentioned five times in the Carakasamhitā, these authors write that it is a drug used entirely as an antidote to poisoning and is probably itself poisonous. They add that it has been identified variously with kākatindu, mahānimba ${ }^{13}$ etc., and that kākatinduka is either Diospyros montana Roxb. known as vișatendū, or Strychnos nux-vomica Linn., also known as kākapīlu, vāyasapīlu or kup̄̄lu.

\section{vāyasapīluka}

The first to be examined among these names is vāyasapiluka, a word found once in the Carakasaṃhitā, in a verse from the chapter on poisons and the treatment of poisoning (Ci. 23.217).

The verse runs:

\section{$k \bar{a} k \bar{a} n d a r a s a s a m y u k t o$ vișānām tandulīyakah /} pradhāno barhipittena tadvad vāyasap̄̄lukah /|

Translation:

tandulīyaka, together with the juice of $k \bar{a} k \bar{a}$ nda, is [one of the] chief [remedies] against poisons, as is vāyasapiluka [together] with the bile of a peacock.

The verse does not specify, in contrast with the preceding verses, against which type of poisoning the two recipes should be employed. It is the first of two verses closing the section on poisoning by various small animals. The following verse also contains an unspecific prescription (called pañcaśirissāgada) against all kinds of poisoning. The subsequent couple of verses is on the treatment of poisoning due to the nails and teeth of quadrupeds and bipeds.

13 Identifications of mahānimba are: Ailanthus excelsa Roxb., Ailanthus triphysa (Dennst.) Alston, Melia azedarach Linn., Melia dubia Cav., and Murraya koenigii (Linn.) Spreng. 
The plant called tanduliyaka is mostly identified as Amaranthus spinosus Linn.; other species of Amaranthus are also regarded as tanduliyaka and used as pot-herbs and medicinal plants.

The bile of animals, in particular that of a peacock, is not an unusual medicinal substance. ${ }^{14}$ The presence of this item points to a medicinal recipe for wealthy people; peacocks were a regular food at the royal table. $^{15}$

Let us see what the Sanskrit commentators have to say about vāyasapīluka.

The edition with Jejjața's commentary (Ca. [1941]) has a strange note between brackets that may be an emendation by the editor, as suggested by the title page of Ca. (1941) where the edition is described as püritajajjațațikātruțitānśabhāga. This note fills up a lacuna in the manuscript ending with $-k t \bar{a}$ and runs: (vāyas $\bar{\imath} k \bar{a} k a m \bar{a} c \bar{t} t y ~ u) k t \bar{a}$. This emendation is not a happy one. vāyasi is absent from Ca. Ci. 23.217 and the preceding verses. The editor obviously borrowed the remark from Cakrapāṇi's commentary (see below), but misplaced it. Jejjața's own remarks on 23.217 follow and are interesting. They differ entirely from those by Cakra. Jejjata first refers to the plant $k \bar{a} k \bar{a}$ ạda. Though its identity is usually said to be unknown, Jejjata is of the opinion that it is the same as $k \bar{a} k a n a n d \bar{\imath}$. This rare plant name is, in the form of $k \bar{a}$ kanandika , found in the Madanādinighaṇțu (6.16), where it is a synonym

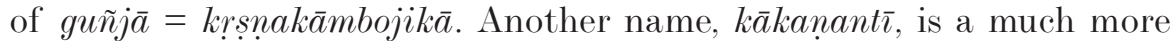
frequent synonym of guñja, Abrus precatorius Linn., the seeds of which are poisonous because they contain the toxic protein called abrin, a ribosome-inactivating substance. An important remark follows: saiva vāyasapīlukah. This cannot but mean that both kākānda and vāyasapīluka designate guñja in Jejjața's eyes, though no nighantu or other lexicon can be found to support this. ${ }^{16}$ We shall come across other authors who also express as their view that vāyasapīluka is identical with guñja. Jejjața, however, is the earliest of them.

14 See, for example, Ca. Ci. 7.170 (barhipitta) and Ca. Ci. 23.51 (śikhipitta); Su. Ci. 9.26 (śaikhina pitta); Aș̣̂añngahṛdayasaṃhitā (A.h. [1939]) Ci. 20.12 (śikhipitta); Aṣțāngasamgraha (A.s.) Ci. 22.22.

15 See the famous rock edict of Aśoka, mentioning the daily killing of two peacocks. See also Chattopadhyay 1967 and 1993b, and Schmidt 1980.

16 Abdul Kareem (1997) gives many other names beginning with $k \bar{a} k a$ - as synonyms of guñja. 
Cakrapānidatta's commentary has only the laconic and at first sight

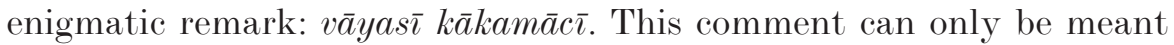
to elucidate vāyasapīluka. No other plant name of the relevant group of verses has any connection with vāyasi, a frequently found synonym of $k \bar{a} k a m \bar{a} c \bar{\imath}$, commonly identified as Solanum nigrum Linn., by some authorities as Solanum americanum Mill. = Solanum nigrum auct. non Linn. ${ }^{17}$

What is Cakra's intention? Does he suggest that vāyasa is the same as vāyasi in this case, thus splitting the compound into vāyasa and $p \bar{\imath}$ luka, as some recent commentators do, or does he propose to regard vāyasapīluka as identical with vāyas̄, a species of Solanum? Whatever he may have meant, it is a strained interpretation. Being a resident of Bengal, the plant called vāyasapiluka may not have been familiar to him. That he may have thought vāyasa to be a plant name is hardly imaginable.

The nineteenth-century commentator Gangādhara (Ca. [1927-1933]) interprets the name as a synonym of kākajangha an unidentified plant also called vāyasajaingha and prācībala. ${ }^{18}$ These three names are, however, conspicuously absent from the Carakasamhitā; they occur in the Suśrutasaṃhitā and Aṣtāñgahṛdayasaṃhitā.

The translations into English of the Carakasampitā are disappointing and give the impression that their authors are prejudice-ridden and blindly accept earlier opinions.

The translation by Kisari Mohan Ganguli, published by A. Chandra Kaviratna (Ca. [1890-1925]), adds the following remark between brackets to vāyasapīluka, which is left untranslated: "otherwise called kākajanghā or Leea hirta Roxb. ex Hornem". This is a now invalid synonym of Leea aequata Linn., which is not poisonous at all. In doing so, the translator follows in the wake of Gangādhara.

The Gulabkunverba translators (Ca. [1949]) render the word as "black nightshade and tooth brush tree", i.e., kākamāci and pīluka, as Cakrapāṇi may have meant.

17 See, for example, Abdul Kareem 1997, s.v.

18 Four plants used as kākajaingha are Peristrophe paniculata (Forsk.) Brummitt = P. bicalyculata Nees, Leea aequate Linn., Vitex peduncularis Wall. ex Schauer, and Abrus precatorius Linn. 
R.K. Sharma and Bhagwan Dash (Ca. [1997]) do not translate the term, adding between brackets " $k \bar{a} k a m \bar{a} c \bar{\imath}$ ", thus obviously taking vāyasapiluka as a synonym of this plant name.

P.V. Sharma (Ca. [1983a]) renders vāyasap̄lluka as kākapīluka and gives in one of his Appendices (p. 724) Diospyros montana Roxb. as the botanical equivalent, a tree with bitter but harmless fruits. No one shares this view with him.

These facts make it clear that no consensus has been reached. Arguments for the identifications are conspicuous by their absence.

The renderings and comments of some of the Hindī translators and commentators are much more illuminating, though the translations by others are as unsatisfactory as those of the translators into English.

Śivaśarman (Ca. [1989] II/1529) renders vāyasapīluka as kākajañghāand $p \bar{\imath} l u$, apparently under the influence of Gangādhara.

Vinaycandra Vāsiṣtha and Pạ̣dit Jaydev Śarmā (Ca. [1954-1962]) are

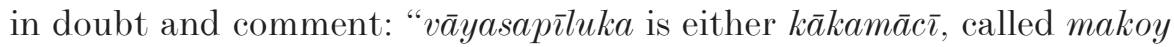
in Hindī, or it is kākatinduka, called kucilā in Hindī." This is important because kucilā is a Hindī name for Strychnos nux-vomica.

Similar thoughts are expressed by Kāśs̄nāth Pāndey and Gorakhnāth Caturvedī (Ca. [1962]). They translate vāyasapīluka as makoy ke mūl, i. e. the roots of $k \bar{a} k a m \bar{a} c \bar{\imath}$, but they acknowledge in their comments that the identity of vāyasapiluka is disputed (vivādgrast) and are of the opinion that Cakrapāṇi regarded the word as a compound and divided it into vāyasa and pīluka. They add that vāyasapiluka is also a name of kucilā, that it is uncertain which plant Caraka had in mind, and that plants like guñja and kākajaingha are known as antidotes.

The most extensive comments are given by Brahmānand Tripāthī (Ca. [1983b]), who does not hesitate to regard väyasapīluka as identical with kucilā. He interprets Cakra's comment (vāyas $\bar{\imath}=k \bar{a} k a m \bar{a} c \bar{\imath})$ as an indication that he divided the word into its two components. He proceeds by saying that if vāyasapiluka is taken as one word, as it is reasonable to do, then it must be the same as $k \bar{a} k \bar{a} d a n \bar{\imath}$. Though the latter is again a controversial name ${ }^{19}$ he regards it as a synonym of kucila, keeping in mind that kākapīlu is a synonym of kupilu. The last name is rather generally interpreted as referring to Strychnos nux-vomica. Tripāthī

19 This plant, absent from the Carakasaṃhitā, has not been identified satisfactorily; see Singh - Chunekar (1972) who remark that the roots, which are recommended for use, are probably more or less poisonous. 
also draws attention to the fact that, though poisonous itself, kucila is, after proper purification, a drug against poisoning. He further refers to A.s. Uttarasthāna (U.) 43.62.

This verse quotes Ca. Ci. 23.217 (cf. above p. 6) with some variants:

kākāndayuktah sarvesām vișānām tandulūyakah / praśasto barhināṇdena tadvad vāyasap̄̄lukah /|

The reading of U. 43.62a is also known from some manuscripts of the Carakasaṃhitā. ${ }^{20}$ praśasta replaces pradhāna, which has no importance. More interesting is that barhipitta has been changed into barhinanda (peahen's egg), either a genuine reading or a scribe's error under the influence of $k \bar{a} k \bar{a}$ ṇda (ef. below p. 15).

Tripāthi also quotes Indu's commentary on the Aștāngaasamgraha. Indu remarks: "kākapīlukah kākapīlukaphalāni, kākapilluko guñjā". With this interpretation he sides with Jejjața.

In the Suśrutasaṃhitā and Aṣțāngahṛdayasaṃhitā references to vāyasapīluka are absent.

Summing up, we have seen that vāyasapīluka may be Strychnos nuxvomica $(k \bar{a} k a p \bar{\imath} l u)$, but that other identifications have also been pro-

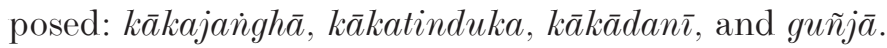

\section{Other Sources Relevant to the Identification of Strychnos nux-Vomica}

The dictionaries do not contribute to a solution. $P W$ does not mention the word vāyasapiluka; $M W$ only says that it is a particular tree, the same as kākapīluka.

$P W$ says about $k \bar{a} k a p \bar{\imath} l u$ that it is the name of several plants: $(1)=$ $k \bar{a} k a t i n d u k a,(2)=k \bar{a} k a t u n d \bar{\imath},(3)$ a variety of Abrus precatorius (śvetaguñja) $;{ }^{21} M W$ says similarly: "(1) the plant Diospyros tomentosa ${ }^{22}$ (kākatinduka), (2) Xanthochymus pictorius ${ }^{23}$ (kākatund $\left.\bar{\imath}\right)$, (3) a variety of Abrus precatorius (śvetaguñjā)". $P W$ adds under kākapīluka: "= kākatinduka", and $M W$ "the plant Diospyros tomentosa (kākatinduka)".

20 See the footnote in Ca. (p. 580).

21 śvetaguñjā is an Abrus precatorius with white seeds; normally, they are black and red.

22 The fruits of Diospyros tomentosa Roxb. are edible.

23 This plant is now called Garcinia xanthochymus Hook.f. ex T. Anderson. 
Thus we see that $k \bar{a} k a t u n d \bar{\imath}$ has been joined to the list of names relevant to the identification of Strychnos nux-vomica. ${ }^{24}$

This resulting list is remarkable because most of the names it contains

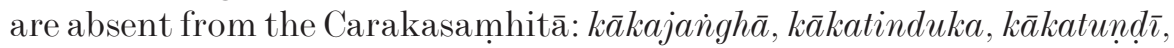
and $k \bar{a} k \bar{a} d a n \bar{\imath}$. The only exception is guñj $\bar{a}$.

$$
k \bar{a} k a \operatorname{tindu}(k a), v i s ̣ a t i n d u(k a) \text { and } k \bar{a} k a p \bar{\imath} l u(k a)(=k u p \bar{l} u)
$$

The most important among these names is kākatinduka. This name is frequent in the nighantus and other lexica. $P W$ gives consistently Diospyros tomentosa Roxb. as its botanical equivalent, as does $M W$.

Consultation of the nighantus yields many synonyms of kākatindu(ka). It will be important to find kākapilu (= kupīlu) among them, which would establish that the two are identical. nighantus that consider the two to be identical are the Rājanighaṇțu (RN) (11[ a mrādivarga].52), Hemacandra's Nighaṇtuśeșa (NŚ) (114), and the Śāligrāmanighantubh $\bar{u}$ șana (p. 597-602).

$P W$ and $M W$ remark about kup $\bar{\imath} l u$ that it is a sort of ebony tree $(=k \bar{a}$ raskara). ${ }^{25}$

When we look for synonyms we find:

Abhidhānamañjarī of Bhiṣagārya (193): rājōmat = karkaśacchada = kula$k a=$ rājōphala $=$ nalaphala $=k \bar{a} k a t i n d u k a ;$

Bhāvaprakāśanighạ̣ṭu (BhPN) (āmrādiphalavarga 66-68): jaladatinduka $=$ dìrghapatrak $a=k u p \bar{\imath} l u=k u l a k a=k \bar{a} k$ atinduka $=k \bar{a} k e n d u=v i s a t i n d u$ = markatatinduka;

Dhanvantarīyanighaṇtu (DhN) (5 [āmrādivarga $] .41):$ dvit̄̄ya tinduka $=$ $k \bar{a} k a t i n d u=$ markatatinduk $a=k \bar{a} k e n d u=k u p \bar{\imath} l u=k \bar{a} k a t i n d u k a$;

Kaiyadevanighaṇțu (oṣadhivarga 400): kāakendukī $=k \bar{a} k a p \bar{\imath} l u=k u p \bar{\imath} l u=$ sthülabinduka;

Madanapālanighaṇṭu (6.40): kākapīlu = kupīlu = viṣatinduka;

NŚ (114): dvit̄ya tinduka $=k \bar{a} k a t i n d u=$ markatatinduka $=k \bar{a} k e n d u=$ kākapīlu = kupīlu = kulaka;

${ }^{24}$ Garcinia xanthochymus is not poisonous; its fruits have a pleasant acid flavour and are used as a substitute for tamarind.

25 The ebony tree is a Diospyros. Both dictionaries refer to the Bhāvaprakāśa as referred to in the Śabdakalpadruma, where kāraskara is said to be a tindukaviśesa. The Bhāvaprakāśanighaṇṭu, however, does not describe a kāraskara. 
RN (11 [āmrādivarga $] .52):$ anya tinduka $=k \bar{a} k a p \bar{l} l u=k \bar{a} k \bar{a} n d a=k \bar{a} k a-$ tinduka $=k \bar{a} k a s p h \bar{u} r j a=k \bar{a} k a b \bar{j} a k a ;$

Śāligrāmanighantubhūṣana (p. 597-602): anya tinduka = jalaja = dīrghapatraka $=k \bar{a} k e n d u=k u p \bar{\imath} l u=k \overline{a k a p} \bar{\imath} l u$.

Lingering over this profusion of names is not necessary. Crucial is that $k \bar{a} k a p \bar{l} l u, k \bar{a} k a t i n d u k a, v i s a t i n d u k a$ and kupīlu are synonyms.

Which are the botanical identifications found in the dictionaries and the secondary literature?

$k \bar{a} k a t i n d u(k a)$ : Almost all the sources give Diospyros tomentosa Roxb., Diospyros melanoxylon Roxb., or Diospyros montana Roxb. The first two species yield substitutes for true ebony, which comes from Diospyros ebenum Koenig, but Diospyros montana has no black heartwood. The authorities I could find who identify kākatindu as Strychnos nux-vomica are Yādavaśarman, ${ }^{26}$ Bāpālāl Vaidya, ${ }^{27}$ and K.C. Chunekar and G.S. Pandey in their edition of the Bhāvaprakāśanighaṇțu. ${ }^{28}$

kākapīlu: see above. See also Madanādinighaṇțu 6.17: dvit̄̄yā śvetakāmboj̄̄

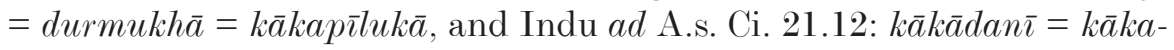
pīlukē.

kupīlu: usually a synonym of kākapīlu.

vișatindu(ka): $M W$ on vișatindu: "(1) Strychnos nux-vomica, (2) a kind of ebony tree with poisonous fruit, Bhāvaprakāśa"; on viṣatinduka: "a species of poisonous plant, Bhāvaprakāśa". $P W$ (s.v. vișatindu): "name of two poisonous plants: $(1)=k$ āraskara, Rājanighaṇțu, $(2)=k u p \bar{l} l u$, Bhāvaprakāśa". It is identified as Strychnos nux-vomica by Bāpālāl Vaidya ${ }^{29}$ Nadkarni ${ }^{30}$ and P.V. Sharma. ${ }^{31}$ The Bhaișajyaratnāvalī of Govindadāsa (55.40) prescribes vișatinduka against a disorder called sparśavāta with anaesthesia (samsparśanajñānavih̄̄natā) as its main symptom.

None of these names occurs in the Bṛhattraȳi. Another synonym, however, found several times in the Carakasaṃhitā, is kulaka. ${ }^{32}$ Cakrapāṇi-

\footnotetext{
26 See his Dravyagunavijūāna (Yādavaśarman 1950-1951: II/270).

27 See his Nighantu Ādarśa (Bāpālāl Vaidya 1985: 60-65).

28 BhPN p. 568.

29 See Bāpālāl Vaidya 1985: 60.

30 See Nadkarni 1954: 1175.

31 See Sharma 1997, s.v.

32 Ca. Sū. 27.97; Ci. 3.189cd; Ci. 17.97ab; Ci. 23.225cd; Ci. 26.156; Ci. 27.27; Ci. 27.34;
}

Ci. 30.74; Ci. 30.259. kulaka is a vegetable $(s \bar{a} k a)$, used as such or in a $y \bar{u} s a$. 
datta's commentary on the Carakasampitā says that it is the same as $k \bar{a}$ ravellaka, ${ }^{33}$ but that others regard is as a variety of patola. ${ }^{34}$ The Dhanvantarīyanighaṇṭu gives two meanings: patolaka and kākatinduka, as does the Bhāvaprakāśanighaṇṭu: paṭola and kupīlu.

Do these works contain other plant names that may refer to Strychnos nux-vomica?

\section{$k \bar{a} k \bar{a} \operatorname{cọ} \mathrm{da}(k a)$ and vișamuș̣i $(k a)$}

There are two candidates to be examined. The first one is found in all three classical treatises, the other one is absent from the Carakasaṃitā. The first candidate is $k \bar{a} k \bar{a} n d a(k a)$, mentioned four times in the Carakasaṃhitā in the chapter on poisoning (Ci. 23.49, 52, 53 and 217). A fifth time it occurs in a variant reading of Ci. 3.267. ${ }^{35}$ Cakrapāni explains $k \bar{a} k \bar{a} n d a$ only at Ci. 23.49, where he reads $k \bar{a} k \bar{a} n d \bar{a}$, though the word ends in $-a$ in the text; he remarks that it is the same as a variety of śimbi, i.e., a plant with pods. A related plant name is $k \bar{a} k \bar{a} n$ dolola , found once only in a variant reading of Sū. 27.34; Cakra, who prefers the reading $k \bar{a} k \bar{a} n d o m \bar{a},{ }^{36}$ regards $k \bar{a} k \bar{a} n d a$ as śūkaraśimbi. Śivadāsasena, whose comments on Sū. 27 are no longer available, but who is nevertheless quoted by Jādavaji Trikamji, ${ }^{37}$ who had at his disposal a more complete manuscript, in his edition of the Carakasaṃhitā (Ca. [1941]), says that it is a pod resembling that of $\dot{s} \bar{u} k a s i m b \bar{\imath} ;^{38}$ the variant reading of Su. 27.34 was also known to him.

The identification of $k \bar{a} k \bar{a} n d a$ is hampered by the references to its $(s v a)$ rasa in three of the passages of the Carakasampitā where it is found. This excludes the use of its seeds. The juice of the fresh wood of Strychnos nux-vomica, however, is also reported to be a popular remedy. ${ }^{39}$

33 Usually identified as Momordica charantia Linn., the bitter gourd.

34 Usually identified as Trichosanthes dioica Roxb. or Trichosanthes cucumerina Linn., used as vegetables.

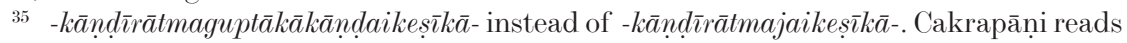
$\bar{a} t m a j \bar{a}$ and does not mention kākāṇ da.

$36 u m \bar{a}$ is a name of Linum usitatissimum Linn.

37 See HIML IB/302, n. 500.

38 Cakrapāni explains the plant name r rsabhī (Ca. Sū. 4.7) as a synonym of śūkaśimbā.

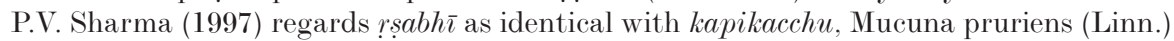
DC., in agreement with Ḍalhaṇa (ad Su. Ka. 7.16). Mucuna pruriens is a herbaceous plant bearing pods.

39 Kirtikar - Basu 1935: III/1646; Chopra et al. 1956: 236; Dastur 1962: 155. 
The Suśrutasamhitā refers to the fruit (phala) of kākānda once (Sū. 46.36). Cakrapanni regards it as a pod (simbaphala) similar to that of śukaśimbz; Dalhana remarks that it is also called aśvaka, that it is a pod (simba) resembling that of kapikacchu, and that its popular name is $s \bar{u} k a r a s ́ i m b \bar{\imath}$. The plant name aśvaka is unknown, except for this passage of Ḍalhaṇa's commentary; Bāpālāl Vaidya ${ }^{40}$ considers it to be a synonym of aśvakhura, i.e., lucerne, Medicago sativa Linn. ${ }^{41}$

The Aṣțāngahṛdayasaṃhitā mentions $k \bar{a} k \bar{a} n ̣$ ḍa once according to Singh - Chunekar 1972, s.v. (A.h. [1939] Ci. 5.20); the name kākāndakī occurs also once (U. 24.35), ${ }^{42}$ as well as $k \bar{a} k \bar{a} n$ dololā (Sū. 6.22). ${ }^{43}$

The Asțāngasamgraha mentions $k \bar{a} k \bar{a}$ ṇda in the verse taken from the Carakasaṃhitā that also prescribes vāyasapīluka (cf. above p. 10). Indu explains it as the eggs of a crow, which is not surprising because in his text the eggs of a peahen also occur. Though $k \bar{a} k \bar{a} n d a$ literally can mean "crow's egg", this sense cannot be right here since the Suśrutasaṃitā once mentions the fruits of $k \bar{a} k \bar{a} n d a$.

The secondary literature is not of much assistance in identifying $k \bar{a} k \bar{a} n d a$. Various and contradictory opinions are found in it.

The Vaidyaka śabdasindhu mentions two identifications of kākānda: (1) $=k \bar{a} k a t i n d u k a,(2)=$ mahānimba, two identifications of its fruit: (1) the fruit of śukaraśimb $\bar{\imath},(2)$ the fruit of kākatinduka, and two identifications of $k \bar{a} k \bar{a} n d \bar{a}$ or $k \bar{a} k \bar{a} n d \bar{\imath}$ : (1) kolaśimb $\bar{\imath}{ }^{44}{ }^{4}$ (2) mahājyotismat $\bar{\imath},{ }^{45}$ while $k \bar{a} k \bar{a} n$ dola is regarded as (1) kolaśimb $\bar{\imath}$ or (2) katabh ${ }^{46}$ Similar entries are found in the Áyurved̄̄ya śabdakośa and Āyurvedīya viśvakośa.

Balwant Singh and Chunekar (1972) remark, rightly so, that the kākān$d a$ of Caraka is a drug used entirely as an antidote to poisoning and is probably itself poisonous; it has been identified with $k \bar{a} k a t i n d u k a$,

40 See Bāpālāl Vaidya 1982: 246.

41 Lucerne is a leguminous plant with pods that do not resemble those of the Mucuna species. Bāpālāl's choice is not happy since Medicago sativa is a native of Southwest Asia.

42 Not explained by Arunadatta.

43 Explained as katabhī by Arunadatta. kațabhī is a very controversial drug; Hemādri regards it as a kapikacchū without bristles (śūka) on its pods.

44 Identified as Canavalia gladiata (Jacq.) DC. = Canavalia ensiformis sensu Baker by Śāligrāma in his nighantu.

45 mahajyotismati is not referred to in the Brhattraȳ, but jyotismatī, mentioned in all three classical treatises, is regarded as either Celastrus paniculatus Willd. or Cardiospermum halicacabum Linn.

46 On katabhī cf. n. 43 above. 
mahānimba and other trees (compare the Vaidyaka śabdasindhu). They add that kākatinduka is either Diospyros montana Roxb. or Strychnos nux-vomica Linn. As the former is not poisonous at all, the latter is the best candidate in my opinion.

P.V. Sharma differs in adducing that, since various commentators say that $k \bar{a} k \bar{a}$ anda resembles $\bar{a}$ tmaguptā, also called kapikacchu, it must be a related plant. ${ }^{47}$ The common kapikacchu is Mucuna pruriens (Linn.) DC. P.V. Sharma identifies kēkānda as Mucuna monosperma DC. ex Wight. He does not explain his reasons for selecting this one among the many species of Mucuna found in India.

The second plant name that may designate Strychnos nux-vomica is visamuști $(\mathrm{ka})$. The name is rare in the Bṛhattraȳ, but common in later works, in particular those on rasaśāstra. It is absent from the Carakasaṃhitā, but found once in the Suśrutasaṃhitā, ${ }^{48}$ the Aștāngahrọdayasaṃhitā ${ }^{49}$ and the Aștāngasamgraha. ${ }^{50}$

Cakrapāni identifies it with brhadalambusāa and adds that others regard it as parvatanimba (= mahanimba). Dalhana comments that it is the same as drekkāa, generally known as rājanimba (= mahānimba), and that others claim it to be either brhadalambușa $\bar{a}^{51}$ or karkoț $\bar{n}{ }^{52}$ Arunadatta (A. h. [1939]) and Śrīdāsapandita (A.h. [1950]), both commentators on the Aștāngahṛdayasaṃitā, interpret it as karkoț $\bar{n}$, remarking that others regard it as mahānimba. Hemādri is silent on the matter. Candranandana equates it with keśamuști in his commentary on the Aștāngahṛdayasamphitā (see A.h. [1956-1957]), ${ }^{53}$ while another commentator on the same work, the Bhāṣyakāra (Vaidya 1936: 526f.), says that it is well known under its own name (svanāmaprasiddha), but that, if not avail-

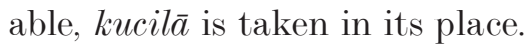

It is impossible to delve deeper into this complicated matter now, but I regard it as probable that vișamuști designates Strychnos nux-vomica.

47 See Sharma 1981: 109.

48 Sū. 38.18: an item belonging to the surasādigana.

49 Sū. 15.30: an item of the same gana.

50 Sū. 16.22: an item of the same gana.

51 Not found in the Bṛhattraȳi; alambusāa, often identified as Sphaeranthus indicus Linn., occurs in the Carakasaṃhitā and Aṣtạng gahṛdayasaṃhitā.

52 Regarded as a synonym of dhāmārgava, Luffa cylindrica (Linn.) M. Roem.

53 Compare BhPN, gudūcyādivarga 97: mahānimba = keśamuști. 
Summarizing again, three Sanskrit plant names from the Bṛattraȳ may be candidates for Strychnos nux-vomica: vāyasap̄luka (or kākapiluka), kākānda $a(k a)$, and viṣamuṣti $(k a)$.

What has been gained so far?

The allegation that Strychnos nux-vomica is absent from early Sanskrit literature has been invalidated for the medical classics. The assertion that the Arabs were the first to introduce it into medicine is based on imperfect knowledge. Furthermore, it appears to be not impossible that the tree was known under different names, as very commonly happens in Sanskrit literature.

kāraskara, kimppāka and viṣadruma - Antiaris toxicaria?

A problematic plant name found in some nighantus and other texts is kâraskara. It complicates matters in the first place because one of its synonyms is visatindu, which is also regarded as a name for $k \bar{a} k a p \bar{\imath} l u$ and kākatinduka, Strychnos nux-vomica. This embarrassing overlap means that two different trees are designated by the name visatindu. Fortunately, this is the only ambiguity; the other synonyms of kâraskara do

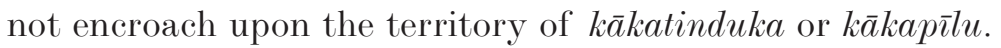

The tree called kâraskara is mentioned in a restricted number of $n i$ ghantus, which is a remarkable feature in itself:

RN 9.35:

kāraskaras tu kimpāko vișatindur vișadrumah / garadrumo ramyaphalah kupākah kālakūtakah //

This verse is repeated in the Śăligrāmanighaṇtubhūṣaṇa (p. 600), which adds about the fruits (p. 602):

asya cāmaphalam grāhi tuvaram vātakṛl laghu/

śtalam ca samuddiștam tat pakvam viśadam ${ }^{54}$ guru //

pāke ca madhuram proktam kapham vātam pramehakam /

pittam raktavikāram ca nāśayed iti kīrtitam //

Abhidhānamañjarī 1106 :

vișavṛsạh kinkirāto viṣah kāraskaro bhavet /

Pāṇini (6.1.156) refers to kâraskara as a plant name.

54 The text has visada, which must be an error. 
$P W^{\prime}$ s and $M W^{\prime}$ 's only remark about käraskara is that it is a poisonous plant. ${ }^{55}$ Śāligrāma regards it as Strychnos nux-vomica, while he does not identify the preceding item, kākapiluka or kupilu.

The entries of the dictionaries on the synonym kimpāka are confusing. $P W$ and $M W$ describe the plant as cucurbitaceous. $M W$ adds that it is Trichosanthes palmata, which has bad-tasting fruits, and that it is Strychnos nux-vomica according to a lexicon.

The fruits of Trichosanthes tricuspidata Lour. = Trichosanthes palmata Roxb., a member of the Cucurbitaceae, are red when ripe; on breaking them open a black smoky powder comes out. ${ }^{56}$ Their seeds are poisonous and extracts of them show haemagglutinating activity. This plant cannot be the kimpakka of the nighantus as it is a large climber, not a tree.

The Rāmāyaṇa (2.66.6ab) refers to kimpāka in an intriguing context. The passage runs: na lubdho budhyate doșān kimpākam iva bhakșayan.

Two translations are possible: "Being bewildered, he is not aware of the bad consequences, like someone who eats a kimpāka (fruit)", and "Being greedy, he is not aware of the bad consequences, as someone who gives (someone else) a kimpāka (fruit) to eat".

The commentary by Rāma throws light on the passage and its double interpretation. Rāma himself gives as his opinion that the kimpāka is a fruit of nimba, Azadirachta indica A.Juss., which has an edible pulp (Wealth of India $\mathrm{I} / 507$ ). This does not elucidate the sense of the expression. Of more interest is his quotation of the earlier commentator Kataka (p. 258a, 15):

katakas tu: kimppāko viṣabhedas tam kopādinā bhakṣayann ātmahatyādoṣam na budhyate tadvad ity artha ity āha. tatra lubdha iti nātyantam samañja-

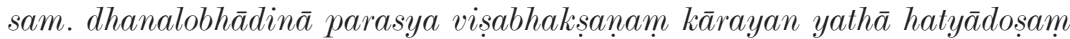
na budhyata iti vaktum ucitam.

This means that Kataka considers kimpāka to be a poisonous fruit whose ingestion leads to certain death, which makes it suitable for committing suicide or murder. He prefers the second interpretation, taking bhaksayati as a causative. Kataka's remarks point to Strychnos nux-vomica as the tree intended and its fruits, not to Antiaris toxicaria and its latex.

${ }_{55} P W$ and $M W$ state that it occurs in the Mahābhārata and Bhāgavatapurāna, referring to Bhāgavatapurāna 5.14.12.

56 Bāpālāl Vaidya 1982: 147f. 
Aśvaghoșa, in his Saundarananda, is also acquainted with the deadly fruits of the kimpa $\bar{k} a$. Verse 9.48 says, in the translation of E.H. Johnston:

Just as eating a kimpa $\bar{a} k a$ fruit leads to death not to nourishment, though its taste, colour and fragrance be good, so application to the objects of the senses leads the man of unbalanced mind to disaster, not to prosperity. ${ }^{57}$

This verse can only refer to the poisonous fruit of Strychnos nux-vomica.

A verse from Vidyākara's Subhāṣitaratnakoṣa (33.1121) refers to particulars of the kimpāka:

When ripe, kimpāka fruit, though bitter and black within, you grow red outside and pleasing to the eye;

yet, I know not what you have thereby to please the heart, unless it be the heart of crows. $^{58}$

The characteristics of this kimpāka are exactly like those of Trichosanthes tricuspidata. Daniel H.H. Ingalls (1965: 545) remarks that this identification is probably correct. He refers to Mārkaṇḍeyapurāṇa 10.31 according to $P W \mathrm{~V} / 1296$, but erroneously ascribes the following text to it: kimpākavrkșasyadhvāinkṣābhakṣantinetare. In fact, Mārkaṇdeyapurāṇa 10.31 reads:

tasmād yāsyāmy aham tāta tyaktvemām duḥkhasaṃtatim / traȳ̃dharmam adharmādhyam kiṃpākaphalasamnibham //

The plant referred to in this verse, whether a tree or a climber, has obviously poisonous fruits, suitable for committing suicide. It would not be Trichosanthes tricuspidata, and is more likely Strychnos nux-vomica or Strychnos colubrina. Ingalls' quotation which states that only crows eat its fruits conflicts with regarding kimpa $k a$ as Trichosanthes tricuspidata, the fruits of which are employed to get rid of crows, as Ingalls himself found out. He writes (Ingalls loc. cit.):

Kosambi write (sic) me as follows: The only local śāstrīs who knew anything about the kimpāka said that its fruit was the kaundal in Marathi. I then found that Nādkarni's Indian Materia Medica identified this kaundala with Trichosanthes palmata. Nādkarni (who says nothing of kimpāka) says that it is mixed with rice to poison crows when these birds get to be a nuisance. ${ }^{59}$

57 Saundarananda 9.48: yathopayuktam rasavarnagandhavad vadhāya kimpākaphalam na puștaye / niṣevyamānā viṣayāś calātmano bhavanty anarthāya tathā na bhütaye //.

58 Translation by Ingalls (1965: 319).

59 See Nadkarni 1954: 1238 (No. 2512). 
Ingalls adds that the same fruit (i.e., the fruit of Trichosanthes tricuspidata) is designated in verse 38.1260 as mahākālaphala.

This verse runs, in Ingalls' translation (1965: 351):

Pleasing outside but black within:-

Who is not fooled by the villain

as by kimpāka fruit?

This mahākāla (rendered as kimppakka here) is undoubtedly Trichosanthes tricuspidata. ${ }^{60}$

Of more importance is what the dictionaries have to say about another synonym of kāraskara (?), namely, visadruma. $P W$ and $M W$ regard it as a kind of poison tree, but $M W$ adds: the upas tree.

This would mean that Antiaris toxicaria, the famous upas tree, was known in India. Will it be possible to confirm this? The other synonyms of kâraskara will also have to be taken into consideration.

The name garadruma, absent from $P W$, is explained as Strychnos nuxvomica in $M W$, though it is not found among the synonyms of kākapīlu or kupīlu.

ramyaphala is, according to $P W$, a particular plant, according to $M W$, Strychnos nux-vomica, despite its absence among the synonyms of this tree name. The name ramyaphala may refer to the fig-like purple fruits of Antiaris toxicaria which are bitter when unripe, but edible when mature. Very remarkable is that Śāligrāma, who identifies kāraskara as Strychnos nux-vomica, does not notice that his information on the fruit is incompatible with this view, but does apply to the fruit of Antiaris toxicaria.

MW considers kupāka to be a name for Strychnos nux-vomica again, to which the same objection as pertains to garadruma applies.

Finally, kālakūta is the name of a famous poison, but whether or not it may be the latex of Antiaris toxicaria has to wait for a closer study.

60 Several authors and works mention mahākāla as the Sanskrit name for Trichosanthes tricuspidata (Lour.) = T. palmata Roxb. = T. bracteata (Lam.) Voigt. Cf. Bāpālāl Vaidya 1982: 147f.: mahākāla as the Marathi name, kimpāka as the Sanskrit name; Dutt 1922: 308; Dymock et al. 1890-1893: II/70; Nadkarni 1954: 1238. The name is rather rarely found in nighantus and similar works. A treatise listing a series of synonyms is the Paryāyaratnamālā (378): urukāla, mahākāla, kimpāka, kākamardaka; this string is repeated in Haricaraṇasena's Paryāyamuktāvalī (17.24). mahākāla is employed in prescriptions expounded in the Kāmaratna (4.79 and 5.81). 
Summarizing, the result of this investigation may be that the upas tree, Antiaris toxicaria, was known in India, though it rarely appears in texts.

\section{The Paippalādasameititā}

An interesting question to which the next part of this paper will be devoted is whether Strychnos nux-vomica may also be designated in some cases and in particular in early or rather early times by the name $p \bar{\imath} l u$, without the specifying $k \bar{a} k a$ - before it.

My interest in this problem was aroused by reading Arlo Griffiths' dissertation, entitled "The Paippalāda Saṃhitā of the Atharvaveda, Kāndas 6 and 7. A New Edition with Translation and Commentary" (Leiden 2004 [Griffiths 2009]). One of the hymns of the seventh kānda attracted my attention. This hymn (7.19) is devoted to the pillu tree, identified by Griffiths as Careya arborea Roxb.

It occurred to me that, since the hymn presupposes a large tree whose ripe fruits harbour poisonous seeds, the strychnine tree, which produces fruits of this character, could be meant.

The identification of the pīlu tree of the Paippalādasamphitā as Careya arborea is improbable since, though a large tree, it does not possess the type of seeds stipulated by the hymn.

Paippalādasaṃhitā (PS) 7.19.3 runs:

yayāhus *trstam katukam apagūdham phale kulam / tasyai hiranyakésyai namah krnmo arātaye //

Griffiths translates:

She by whom, they say, a harsh, sharp pit is hidden away in [its] fruit, to her, the golden-haired Arāti, do we bring homage.

Some comments on this verse are necessary. The $p \bar{\imath} l u$ tree is associated with evil in the form of a demonic being called Arāti, also referred to in PS 7.19.4; this evil being is known from Vedic literature. Another being, egg-eating (andūda) and fetus-spoiling (garbhadūsana), called Arāya, is referred to in PS 7.19.5 as a source of evil to be defeated by the pillu tree; it, too, is a member of a group of demonic beings like those attested in the Paippalādasaṃhitā. 
The pit (kula) is a seed, as is clear from the use of this word in this sense in the Carakasamhitā. ${ }^{61}$ The word tṛta is more problematic, but commonly, according to Griffiths, associated with poison in Vedic texts.

This indicates that a tree with poisonous seeds is described. This certainly did not escape Griffiths's notice. He therefore took recourse, understandably, to Watt who, in his A Dictionary of the Economic Products of India, ${ }^{62}$ remarks, without naming his source, that the seeds of Careya arborea are said to be more or less poisonous. Watt, however, also quotes the Reverend A. Campbell who says that the fruit is eaten by the Santals $^{63}$ and adds from another source, not named, that they are also consumed in the Punjab. ${ }^{64}$ R.B. Mohanty and M.K. Rout (2003) report that the leaves are used as fodder in Orissa and is claimed to enhance the milk production of cattle. The later secondary literature rarely refers to a poisonous character of the seeds. ${ }^{65}$ James A. Murray is one of the few who give information on this matter. He remarks in his The Plants and Drugs of Sind that Endlicher says that, although the fruit is eaten, the seeds are suspicious. ${ }^{66}$ This Endlicher is probably Stephan F.L. Endlicher, a botanist who lived from 1804 to 1849; among the number of books he wrote the quoted remark may be from his Enchiridion botanicum, published in 1841. Several authors mention that the root, bark and leaves are employed to kill fish, but the fruit is only referred to in that context by S.P. Agharkar. ${ }^{67}$ Conclusive investigations on this issue are not known to me.

Careya arborea can thus be discarded rather safely as a possible identification of the pillu of the Paippalādasamhitā. ${ }^{68}$

It may even be argued that pilu rarely designates this tree, despite entries in the authoritative dictionaries. Both $P W$ and $M W$ give as the first identification of $p \bar{\imath} l u$ Careya arborea. It is still enigmatic to me whence this information stems. The tree is almost nowhere called $p \bar{\imath} l u$ in works on the Indian flora and Indian materia medica; the only exception is the

${ }^{61}$ Ca. Ci. 1.1.75: akulaka; Cakrapāṇidatta: = anasthan.

62 Watt 1885-1893: II/157.

63 Bodding 1925-1940, however, does not mention Careya arborea as used by the Santals in their medicine or as a tree with edible fruits.

${ }_{64}$ McCann (McCann n.d.: No. 8), probably relying on Watt (see his Preface), also mentions that the fruits are eaten in the Punjab and given to cattle.

${ }_{65}$ McCann, probably relying on Watt again, remarks that the seeds are regarded as poisonous. A similar statement is found in Pandey 2001: 320.

${ }_{66}$ Murray 1881: 194.

67 Agharkar 1953: 245.

68 The tree is not mentioned in Chopra et al. 1940. 
work of Kirtikar - Basu (1935). The most common name is always $k u m b h \bar{\imath}$, an appropriate appellation. The name derives from a peculiar cavity within the fruit, at its apex, which makes it resemble a kumbha, a water-jar. "Belegstellen" where pīlu must be interpreted as Careya arborea are not easily discovered, but may be found by means of a careful study of the relevant context.

The second identification given in the standard dictionaries is Salvadora persica Linn. This is not a large tree, but more usually a shrub, and has no connection whatsoever with the pīlu of the Paippalādasamphitā. No parts of it are poisonous. It is well known as one of the trees that yield tooth sticks (dantakāsțha), though some Dharmaśāstra works (VS 61.4) forbid the use of this particular tree for the purpose (cf. below p. 39f. and n. 121).

Usually, the pīlu of Sanskrit literature is a Salvadora species, either Salvadora persica Linn. or Salvadora oleoides Decne. Both resemble each other and can be used for the same purposes. The main difference is the colour of the fruits. Whether one of the two may be the brhatpilu distinguished in some of the nighantus cannot be decided; there is no clear-cut difference in the size of the trees themselves, but the dimensions of the fruit may be decisive in this respect. ${ }^{69}$

Careya arborea Roxb. is a large deciduous tree, found throughout a large part of India. The simple and stalked leaves are alternate, oval and dentate, crowded at the end of branches. The sessile, showy flowers with four sepals, four petals and many stamens are large and pinkish or yellowish white, clustered at the end of branches in short spikes; they usually appear in April, generally when the tree is destitute of leaves. The green fruits are ovate berries of the size of an apple (ca. $8 \mathrm{~cm}$.), contain many seeds embedded in fleshy pulp, and have a peculiar and unpleasant smell. They are surmounted by an enlarged mouth having a depressed pit at the vertex within the calyx-teeth and the remains of the style. The thick and exfoliating grey bark with shallow cracks is used by a sect of $s \bar{a} d h u$ s to cover their bodies and on account of this the sect is known as Kumbhapatiā. The moistened bark gives out a mucilage.

Salvadora persica Linn., on the other hand, is a small, thick-stemmed and soft-wooded evergreen tree or shrub, found in low and arid land. The trunk is generally crooked and the bark deeply cracked. The numerous

69 Cf. RN 11.63: anyaś caiva bṛhatpīlur mahāpīlur mahāphalah / rājapīlur mahāvṛkso madhupiluh sadāhvayah //. This pīlu is called mahāphala; the name madhupīlu precludes that it is Careya arborea. Kamat (2006: 13) regards the brhatpīlu as Salvadora oleoides. 
spreading branches are pendulous at their extremities. The opposite leaves are entire, oval, smooth and shining on both surfaces. The numerous small, greenish yellow flowers appear in terminal compound panicles. The plant is flowering and fruiting nearly all year. The fruits are globose, minute, smooth berries, red when ripe, with an aromatic smell and taste, not unlike garden cress.

Salvadora oleoides Decne. resembles S. persica closely and is found in the same type of ecosystem. Its leaves are linear-lanceolate. Its flowers are greenish white. The fruits are also similar, but yellow when ripe.

The confusion about the identity of $p \bar{l} l u$ created by the dictionaries is well illustrated in the etymological Sanskrit dictionaries of Manfred Mayrhofer, who opted for Salvadora persica in the first version (Mayrhofer 1956-1980: II/295f.), but for Careya arborea in the later version (Mayrhofer 1986-2001: II/138f. and III/326).

In summary, we see that the dictionaries and the secondary literature are of no avail in establishing the identity of the Paippalāda pīlu, which must be some other tree.

The identity of the $p \bar{\imath} l u$ is unfortunately not elucidated by the plant called piluparn $\bar{\imath}^{70}$ The plants adduced in $P W$ and $M W$ do not possess leaves resembling those of Careya or Salvadora. Another species, regarded as pīluparñ $\bar{\imath}$ in the literature, Maerua oblongifolia (Forsk.) A. Rich., has similar leaves, but completely different properties. In general, the ending -parñ $\bar{\imath}$ after a plant name does not even unambiguously indicate that the leaves of such a plant are similar to those of the plant designated in the first part of the compound. Balwant Singh and Chunekar give as an example mūlakaparṇ̄, a synonym of śigru, Moringa oleifera Lam., which does not mean that the leaves of sigru resemble those of mulaka, Raphanus sativus Linn., but that "its root and root-bark are like mülaka ... in taste ... and medicinal properties". ${ }^{71}$

The word pillu is rare in Vedic literature. It is absent from the Rgveda. The adjective pīlumat is found once in the Saunakiya recension of the

${ }^{70} P W$ gives three plants: "(1) Sansevieria zeylanica Willd., (2) Momordica monadelpha Roxb. [an old name for Coccinia grandis (Linn.) Voigt = Cephalandra indica Naud.], (3) ein bestimmtes Heilkraut". $M W$ mentions Momordica monadelpha and adds that it is also a certain drug.

71 Singh - Chunekar 1972: 398. 
Atharvaveda (18.2.48), where it qualifies the middlemost heaven. The second occurrence is at 20.135.12. ${ }^{72}$

The question to be discussed further is whether or not Strychnos nuxvomica Linn. is a proper candidate for the referent of the word pilu.

As to its characteristics, it is suitable. Moreover, one would expect it to be mentioned in later Sanskrit literature. Its presence in Vedic literature, however, is more problematic. The Paippalādasaṃhitā is a text that originated in Northwestern India, where the tree does not grow nowadays. I do not know whether this was also the case in Vedic times. Climate changes and/or deforestation may have altered the situation. A very early commercial route between the northern and southern parts of India has to be assumed if the tree was absent from the North. The seeds of Strychnos nux-vomica pose no problem in themselves. They are usually dried and are easily transportable.

The solution of the problem is not possible in the present state of our knowledge. ${ }^{73}$

\section{VArious Sanskrit Sources}

Other works known to mention pīlu have been examined by Renate Syed in her thesis "Die Flora Altindiens in Literatur und Kunst" (Syed 1990). She concludes that in all the places she studied a Salvadora is meant. This conclusion may be premature and contestable in a number of cases.

$$
p \bar{\imath} l u \text { - Salvadora persica or Careya arborea? }
$$

The texts examined by Syed are:

(1) Atharvaveda 20.135.12:

tvám indra kapótāya chinnapakșáya váñcate / śyámākam pakvám pílu ca vấr asmā ákṛnor bahúh //

You, o Indra, provided for the staggering pigeon whose wings were clipped much ripe millet and pīlu-fruit, [and you provided] water for it (transl. Griffiths 2009: 437).

72 See on these passages Griffiths 2009: 435-438. Whitney's translation (1905) of Atharvaveda 18.2.48 is: "Watery is the lowest heaven, full of stars (? pīlu) is called the middlemost; the third is called the fore-heaven, in which the Fathers sit."; for 20.135.2 see below.

73 The interesting fact remains that the seed of pīlu is called kula in the Paippalādasaṃitā, a term used as a synonym of Strychnos nux-vomica in later Indian literature. 
O Indra, der Taube, deren Flügel abgeschnitten waren und die sich schwankend bewegte, hast du reife Hirse ${ }^{74}$, pillu und reichlich Wasser gegeben (transl. Syed 1990: 443).

Syed may well be right in regarding this $p \bar{\imath} l u$ as Salvadora persica; its fruits are sweet, edible, and easily procurable in dry regions of India. However, it can also be Salvadora oleoides, whose fruits are also sweet and edible, and sometimes fed to cattle. Salvadora oleoides is found in the arid parts of the Punjab and western India. Less probable is that the fruits of Strychnos nux-vomica are meant, though many birds are said to be fond of their pulp that contains only small amounts of toxic alkaloids. These fruits would not have been easily procurable.

(2) Harșacarita 3 (p. 95; from the description of the region named Śrīkaṇtha):

pade pade karabhapālibhih ... (drākṣālatāmaṇdapaị /) ... pīlu pallava-

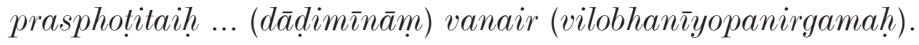

At every step are groups of young camels. (The exits are made attractive by vine-arbours and pomegranate orchards;) arbours, ablaze with pillu sprays ... (transl. Cowell - Thomas 1897: 80).

Rundherum waren Wälder, in denen die pīlu-Schößlinge aufbrachen, versehen mit Kamelgruppen ... (transl. Syed 1990: 443).

The translations of pilupallavaprasphotita are not very accurate. The meaning is clearly that these trees have begun to bloom; the flowers are present in loose panicles, but the trees cannot be ablaze with them as their colour is greenish white or greenish yellow. In this case the pilu may be Careya arborea, occurring throughout India, a tall tree and not a shrub as Salvadora, ${ }^{76}$ and with showy flowers (cf. above p. 26). Its leaves are a favourite fodder for camels.

(3) Harșacarita 8 (p. 235; from the search after the mendicant Divākaramitra):

nirbhayabhūribhuruṇdabhujyamānapākakapilap̄lavah $\ldots^{77}$

${ }^{74}$ The usual identification of śyāmāka is Echinochloa frumentacea Link = Panicum frumentaceum Roxb. This kind of millet, cooked in water like rice, is consumed mostly by the poorer classes; the grains are also used for feeding cage birds (Wealth of India ${ }^{2}$ III/125f.).

75 Commentary: pīlur vṛkșabhedah.

76 Syed regards also this pīlu as Salvadora persica. Sharma (1975b) thinks that pīlu designates this tree wherever it is found in Bāna's works.

77 Commentary: bhurundāh paksibhedāh; pīluphalam sramsīkam. Several nighantus mention sramsī as a synonym of pīlu: BhPN, āmrādiphalavarga 128; NŚ 139; Kaiyadevanighaṇtu, oṣadhivarga 452; Soḍhalanighaṇṭu (SN), nāmasamgraha 575cd. 
The bhurundas were fearlessly eating the ripe brown-red fruit of the pillu trees ... (transl. Cowell - Thomas 1897: 234).

Furchtlos verzehren die zahlreichen bhurunda's die reifen, braunroten pīlu(-Früchte) ... (transl. Syed 1990: 443).

\section{The bhurunda / bherunda bird}

The bhurunda, also called bhāranda, bhärunda and bherunda, ${ }^{78}$ is mentioned in the Mahābhārata:

MBh 3.170.43ed and 47ed = MBh (B) 3.173.48ab and 52cd:

śālāvrkānām pretānām bhuruṇdāṇām ca sarvaśah //

sarvam āsīj jagad vyāptam tasminn astre visarjite //

Hyenas, ghosts, bhurundas ... filled up all the universe when that weapon was launched (transl. van Buitenen 1975: 551).

MBh 3.198.35a-d $\approx$ MBh (B) 3.207.36a-d:

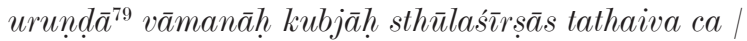

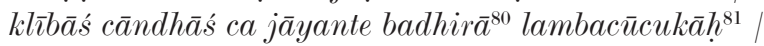

People are born stunted, ${ }^{82}$ dwarfish, hunchbacked, large-headed, impotent, blind, deaf, drooping, and stammering [...] (transl. van Buitenen 1975: 620).

MBh $6.8 .11 \approx \mathrm{MBh}(\mathrm{B}) 6.7 .12$ (from a description of the country of the Uttarakurus):

bhārund̄ā nāma śakunās tīkṣnatund̄a mahābalāh/ te nirharanti hi $i^{83}$ mrtān darìsu praksipanti ca /|

78 See on this bird: Hopkins 1915: 20; Mayrhofer 1956-1980: II/496 and 1986-2001: III/368, s.v. bhāranda; Stache-Rosen 1977. Stache-Rosen (p. 492, n. 34) refers to a monograph and an article in Kannada: Devulu Narasimha Sastri, Bherundeśvara, Mysore Insurance Company (year unknown), and M. Hanumantha Rao, Gaṇdabheruṇ̣a, in: Savinenapu. Festschrift for Prof. T.S. Venkannaya, Mysore 1970, p. 651-659. She discusses several images of Gaṇdabheruṇda, coins, inscriptions, etc., in her article. A particular gesture of dancers, called after bherunda, is described in Nandikeśvara's Abhinayadarpaṇa, v. 203.

${ }^{9} \mathrm{MBh}(\mathrm{B})$ : bherundā.

${ }^{80} \mathrm{MBh}(\mathrm{B})$ : badhirā jāyante.

81 MBh (B): 'tyuccalocanāh.

82 It is not clear why van Buitenen rendered urunda as "stunted". Nīlakaṇtha: bherundāh = bhayānakāh .

${ }_{83} \mathrm{MBh}(\mathrm{B}): \tan$ nirharantīha. 
$\mathrm{MBh} 12.91 .21 \mathrm{~cd}=\mathrm{MBh}(\mathrm{B}) 12.89 .22 \mathrm{~cd}($ see also $\mathrm{MBh} 12.94 .36 \mathrm{~cd}=\mathrm{MBh}$ [B] $12.93 .37 \mathrm{~cd})$ :

bhārundasadṛsā hy ete nipatanti pramādyatah $/\left.\right|^{84}$

MBh (B) 12.169.9-10ab ( MBh 12.163.9):

samantato dvijaśreșthās tatrākūjanta vai tad̄̄ manuṣavadanāś cānye bhārund̄a iti viśrutāh /| bhūlingaśakunāss ${ }^{s 5}$ cānye sāmudrāh parvatodbhavāh /

Another work referring to these birds is the Pañcatantra. ${ }^{86}$ The Viṣnusmṛti (VS) is acquainted with Vedic mantras called the Bhāruṇdas. ${ }^{87}$

Further sources mentioned by Valentina Stache-Rosen (1977) are: the Parāśarasmṛti ${ }^{88}$ and the Śatruñjayamāhātmya, ${ }^{89}$ some other Jain works,

${ }^{84}$ Commentary by Nīlakantha: bhārunda = gṛdhra .

${ }_{85}$ E.Washburn Hopkins (1915: 20) associates the bhärundas with the bhülinga birds of the Mahābhārata who also have a human voice and are reckless, even picking the lion's teeth. The relevant verses (MBh 2.41.19-21; MBh [B] 2.44.28-30; also quoted by Dave 1985: 362) are: bhūlingaśakunir nāma pārśve himavatah pare / bhīsma tasyāh sadā vācah śrūyante 'rthavigarhitāh // mā sāhasam iț̄dam sā satatam vāsate kila / sāhasam cātmanātīva

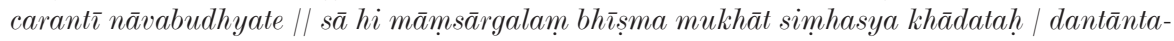
ravilagnam yat tad ādatte 'Ipacetana //. The commentator Nīlakaṇtha calls the bhülinga a bilaśāȳ pakṣiviśeșah; he explains māmsārgala as: daṃstrāntaralagnasya māmsasya bahirnirgatabhāgam ullolam. Dave brings forward that simha does not denote a lion here, but a crocodile; he does so because he regards the bhülinga as the African plover, Pluvianus aegyptius, commonly known as the crocodile bird. This bird owes its name to its frequent association with the Nile crocodile from the body of which it picks out parasites; as the monster is sunning itself on the bank with its mouth agape, the bird boldly enters it to draw out the leeches sticking to the jaws. It also renders another service to the crocodile, in that, being a very wary bird, it flies off with warning cries at the approach of danger; the crocodile taking the warning then slips into the water. It will be readily seen that for Dave the leeches are the māmsa and the warning cry of the birds the mā sāhasam cry of the Mahābhārata story. It is probable, according to Dave, that in former times the plover frequented the Sind coast or the estuary of the Indus river, or else that the ancient Indians heard of the bird's habits from the seafaring merchants of ancient India. However, this suggestion is fanciful and unconvincing. A bird called bhiluinga, mentioned in the Paesi-kahānaya, cannot be the same as the bhülinga, if this is indeed an aquatic bird, but reminds one more of the carnivorous bherunda, according to Bollée 2005: $69 \mathrm{f}$.

86 Pañcatantra, aparīkșitakāraka (5), bhāruṇdapakșikathā (13).

87 VS 56.3 (13). Jolly (1880: 185) says in a footnote to his translation that Bhārunda is the name of certain sammans, twenty-one in number, which begin with Rgveda 10.16.6 (see Nandapandita's commentary); cf. MBh (B) 1.70.39, quoted below in n. 103.

88 Dave (1985: 397) quotes from Pārāśarasmṛti 6.7: bheruṇ̣acāsabhāsāś ca parāvatakapiñjalau.

${ }^{89}$ See Weber 1858: 31 (referred to in Stache-Rosen 1977: 491). The bhärandas are called khilapakșinah, translated as "Wüstenvögel" by Weber (loc. cit., n. 1). 
specifically the Sūtrakṛtānga ${ }^{90}$ and the Uttarādhyayana, ${ }^{91}$ the Kathāsaritsāgara, ${ }^{92}$ Brahmapurāṇa, ${ }^{93}$ Brahmāṇḍapurāṇa ${ }^{94}$ and Ś Sivapurāṇa, ${ }^{95}$ and the Yaśastilakacampu ${ }^{96}{ }^{96}$ as well as some lexica: Hemacandra's Anekārthasaṃraha, ${ }^{97}$ the Viśvaprakāśa ${ }^{98}$ and the Dvirūpakośa. ${ }^{99}$ Left unmentioned by her is the Padmapurāna. ${ }^{100}$ The Medinīkośa mentions a goddess and a Yakṣiṇi called Bheruṇ̣āa. ${ }^{101}$

Additional material on the bherunda, in particular in Jain works, is found in a book by Willem B. Bollée; ${ }^{102}$ K.N. Dave in his work on birds in

${ }_{90}$ Sūtrakṛtānga 2.2.70: "(There are monks) who are always waking like the fabulous bird Bhāruṇḍ" (transl. Jacobi 1895: 378).

91 Uttarādhyayana 4.6: "Be always watchful like a bhārunda bird" (transl. Jacobi 1895: 19). In a footnote Jacobi adds that each of these birds has two necks and three legs.

92 See Tawney 1924-1928: II/219, n. 2, and III/60-63: the "overhearing" motif.

93 Brahmapurāna 164.3-37: a story about King Pavamāna's conversation with a ciccika bird named Bherunda; this bird says that nobody is afraid of it and that it is not afraid of anybody.

94 Brahmāṇḍpurāṇa 3.4.19.4, according to Stache-Rosen 1977: 492, n. 31, and 3.4.24.49: vikarṇākhyaś ca daityendraś camūbhartā mahābalah / bherundapatanārū dhah pracandayuddham ätanot //.

${ }_{95}$ ŚSivapurāṇa 2.5.49.12 (for the beginning of the sentence, cf. 2.5.49.3cd-4a: maheśvarāt punarjātah śukro vedanidhir munih // dadarśa ...): aghoram ghoradaityaghnam ghoraghoșam vanaspatim / bhasmāngam jațilam śuddham bheruṇdaśatasevitam //.

96 Yaśastilakacampū 1.144.4 according to Stache-Rosen 1977: 492, n. 28.

97 Anekārthasaṃraha 3.188c: bheruṇdau bhēsaṇakhagau (compare the quotation in Dave 1985: 397).

98 Viśvaprakāśa p. 45, v. 32cd: bherundo devatābhede paksino bhidi ceṣate. Dave quotes from the same work: bherundo bhìmadarśanapakșino bhidi (Dave 1985: 397).

99 Stache-Rosen (1977: 493, n. 38) refers to the Dvirūpakośa of Śrīharṣa, ed. Ranganathaswami, Vizagapattam 1896, v. 151.

100 See Dange 1986: 127 (referring to Ādi 4.2-12).

101 Medinīkośa 13.34cd.

102 See Bollée 2005: 70 with notes 1-2. Bollée refers to his own book of 1995 (p. 167), to Kapadia 1962, to Haribhadra's Āvassayanijjutti (one pair of the bird has three legs: tesim jugalassa tinni pāyā), to the Paṇnavanāsutta (1.78: the bhāranda is called a

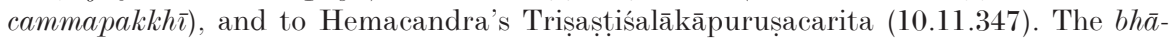
rundas are mentioned in the story about Kumāranandin and Nagila (10.11.333-387): "Embarked with Kumāranandin, after he had gone a long way on the ocean-path, the old man said: 'Look here, please. On the shore of the sea at the foot of a mountain one can see a fig tree. Cling to this when the boat passes underneath. The bhärundas, threelegged birds, will come here from Pañcaśaila. While they are asleep, bind yourself firmly with a cloth to the middle foot of one of them and hold on with a tight grip. At daylight, you will reach Pañcaśaila by the bhärundas flying up. Later the boat will perish in the whirlpool and, if you do not cling to the fig tree, you also will perish in the same way, alas!"” (transl. Johnson 1962: 286). Kapadia (1962: 81-83: bhāranda/bhārunda), in his turn, refers to further passages where the bhāraṇda is mentioned: Śĩlānka Sūri’s com- 
Sanskrit literature also refers to several additional sources. ${ }^{103}$ A treatise left unmentioned so far is the Vasudevahiṇdi. ${ }^{104}$

K.N. Dave defends his view that three kinds of bherunda are to be distinguished: (1) the two-faced type, which may be the dodo, ${ }^{105}$ (2) the bearded vulture, Gypaetus barbatus (L.), and (3) the adjutant stork, Leptoptilos dubius (Gmelin 1789). ${ }^{106}$ The fruit-eating bhurundas of Bāna's Harșacarita are out of tune with carnivorous vultures and storks,

mentary on the Sūyagaḍa Nijjutti (v. 108), Mahānisīha 9.693, Nāyādhammakahā 1.5, Ovavāiya s. 27, and Pajjosavan̄ākappa s. 118.

103 Additional sources as given by Dave are: Hemacandra's Deśīnāmamālā: bherundo citrakah (this quotation by Dave is not from the Deśīnāmamālā, but from the commentary; the text itself has at 6.108: bherundo dīvī bhoyabhoiya bhādigāmapavaresu / ahiyārisambale bhollayam ca bhārundayammi bhorudao //, and the commentary runs: bherundo citrakah, bhoo bhātih, bhoio grāmapradhānah, bhollayam prabandhapravrttam pātheyam, bhorudo bhāruṇdapakșī. yathā: anutittham kayabhoyā ekkamuhīhavia bhollayam leha / bhoiyabherund̄̄ domuhabhorudayāna pecchaha avāyam //); MBh (B) 1.70.39: bhārundasāmagītābhir atharvaśirasodgataih / yatātmabhih suniyataih śuśubhe sa tadāśramah //; Matsyapurāna 6.16f. (on dvimūrdhan śakuni belonging to the progeny of Danu): danuh putraśatam lebhe kaśyapād baladarpitam / vipracittih pradhāno 'bhūd yeșām madhye mahābalah // dvimūrdhā śakuniś caiva tathā śañkuśirodharah / ayomukhah śambaraś ca kapiśo vāmanas tath $\bar{a} / /$, and 6.35f. (bherunda as a son of Jațāyus): sampātiś ca jațāyuś ca arunasya sutāo ubhau / sampātiputro babhruś ca śñghragaś cāpi viśrutah // jațāyuṣah karnikāạah śatagāmī ca viśrutau / sāraso rajjuvālaś ca bheruṇdaś cāpi tatsutāh //; Nāradapurāṇa 3.77.88: bheruṇd⿳亠㐅冋 vāyasā grdhrā hamsādyāh paksijātayah (3.77.85-90: "May these be destroyed: ... all those different types of beings which desire to attack us during twilight, by day or by night"); Nighanturatnākara: galeśunda pakșiviśssa (I have not been able to find the passage on the galeśunda although the index called Vaidyakaśāstrāntīla pāribhāsikik śabdāncā koṣa for vol. 1 of the Nighaṇturatnākara [p. 55] says: galeśunda pakṣiviśeșa); Pariśiștaparvan of Hemacandra 2.2408: velādharo bhārandah; Ristasamuccaya of Durgadeva 176a: giddhūlūya bhārayado (grdhrolūka bhāranda) (translation by Gopani: "[It is not good, if one of these is seen, namely,] a vulture, an owl, a bhāranda (a fabulous bird) ..."; Sabdārthacintāmaṇi: bhāraṇda uttarakurudeśajaśakunapakșin.

104 This work contains a story called "The journey of Cārudatta", in which a group of merchants is instructed by the caravan leader to kill the goats they have been riding and to slip into their hides so that the bhärunda birds mistake them for raw meat and carry them off to Ratnadvippa (see Jagdishchandra Jain's Introduction to his translation p. 48 and his translation p. 290-298). Jagdishchandra Jain refers to Haribhadra's commentary on the Āvassaya, as Bollée does, and gives a summary of the story found there (together with the gist of a similar story by Śaktideva in Kathāsaritsāgara 2.218f.). He also refers to the commentary on the Uttarādhyayana (18.251f.). Finally, he draws attention to comparable stories about the bird Rukh, also called Seemurgh, in the "Arabian Nights". The daring (dhrsta) birds with iron beaks (ayastunda) of the Buddhacarita (14.14) may be related to the bherundas.

105 Dave's defense of this improbable suggestion will convince no one.

106 Dave 1985: 397-399. See the descriptions (and the corresponding colour plates) of these birds in Ali - Ripley 1983: 314-316 (no. 188) and 105-107 (no. 67). 
and the dodo has never roamed on India's soil, which makes Dave's suggestions inapplicable to the case under discussion.

Dave also suggests that a bird mentioned in the commentary on the Vessantarajātaka, where it is called a hatthilingasakuna, may be the adjutant stork because it is characterized as a bird capable of taking away small children. ${ }^{107} \mathrm{He}$ argues that this stork readily swallows a leg of mutton or a dead cat entire, and would strike at any living thing it can swallow at a gulp. In the Bakajātaka this bird is said to be ready to attack a lamb or kid. A second argument in support of this identification is, in his view, the 12 to 15 inch pendent pouch of the bird that resembles the trunk as the characteristic mark (linga) of the elephant (hastin). Dave is in doubt, however, and adds that also the bearded vulture was formerly reputed to carry off small children.

In the context of Harșacarita 8, the colour of the pilu fruits is important: Salvadora persica has red fruits, and those of the closely related Salvadora oleoides are yellow. The colour kapila throws some doubt on Syed's identification because it means reddish brown, monkey-coloured; this also excludes the fruits of Careya arborea and Salvadora oleoides, but not those of Strychnos nux-vomica, which can indeed have this hue.

The second point is the fearlessness of the bhurunda birds. Is there no danger around or are they not afraid of the fruits? The latter would point to the fruits of Strychnos nux-vomica with their poisonous seeds. The large size of bhurundas is also in favour of Strychnos nux-vomica, the fruits of which are a delicacy to large birds, hornbills for example. An objector might argue that the reference to two completely different $p \bar{\imath} l u$ trees in one and the same literary work is not very attractive, but a poetic mind like that of Bāna cannot be expected to describe nature with the accuracy expected of a scientist. The option that nirbhaya is a fixed characteristic of the bherunda birds in this instance, as it is actually sometimes observed, appears inappropriate because it is followed and not preceded by the qualification bhüri.

Let us continue with the survey of the sources adduced by Syed for her identification of pīlu as a Salvadora.

107 Jagdishchandra Jain (cf. Vasudevahinḍi p. 291) also mentions this huge bird called hatthilinga referred to in the Jataka commentary and adds that it is described as possessing the strength of five elephants. According to him, a hatthilinga also figures in the Dhammapada commentary where Queen Sāmavatī, wearing a red cloak, is mistaken by this bird for a piece of meat. 
$p \bar{l} l u$ - Salvadora Persica or Careya arborea (continued)

(4) $\mathrm{MBh} 2.47 .4=\mathrm{MBh}(\mathrm{B})$ 2.51.4:

aśvāms tittirikalmāsāmẹs triśatam śukanāsikān / uștravāmīs triśatam ca puștạh pīluśameñgudaih /|

(Der König von Kamboja gab als Tribut) 300 papageiennasige Pferde der Tittiri- und der Kalmāśa-Rasse sowie 300 Kamelstuten, wohlgenährt durch pīlu, śamı̄ und inguda (transl. Syed 1990: 443).

(The Kāmboja gave as tribute ...) horses, gray and dappled, three hundred of them, with beaklike noses, and three hundred camel mares fed with dates, śamì, and inguda nuts (transl. van Buitenen 1975: 116).

The leaves of both Salvadora persica and Salvadora oleoides are still used as camel fodder, but Careya arborea is also a good fodder tree, ${ }^{108}$ which makes the identification of this pillu difficult. The reason for van Buitenen's rendering pillu as "date" is an enigma; this meaning is not recorded in the dictionaries. The leaves of $i \dot{n g} u d a$, Balanites aegyptiaca (Linn.) Delile, are not a good fodder for horses because this droughthardy tree is spiny; they are eaten by cattle, sheep and goats. Its fruits are erroneously called nuts by van Buitenen; they contain a stone-like kernel and their pulp is edible, but they are not used as food for camels. The pods of śami are used as fodder for livestock (cf. below p. 38f.).

The verse MBh 2.47.4 gives rise to more problems. Horses with noses like those of parrots or beaklike noses may not exist. tittiri and kalmāsa are not names of particular races $(k u l a)$ of horses, as Syed assumes. A breed called taittila is described in the Sivatattvaratnākara (7.13.34-37) as an upakula of saindhava, not of kāmboja horses; it is also mentioned in Someśvara's Mānasollāsa, and Nakula's Aśvaśāstra calls it taittika. I think, agreeing with van Buitenen on this point, that tittiri and kalmāsa are colour names, not names of breeds. This is confirmed by the commentator Nīlakantha who explains tittiri as tittiripakșivac citra, i.e., of a variegated or spotted colour as the tittiri bird, a partridge. kāmboja horses, on the contrary, are well known and usually found at the head of lists of horse breeds. ${ }^{109}$

(5) $\mathrm{MBh} 3.174 .23 \mathrm{~cd}=\mathrm{MBh}(\mathrm{B}) 3.177 .23 \mathrm{~cd}$ :

bilveñgudāh pīluśamīkarīrāh sarasvatītīraruhā babhūvuh //

bilva, inguda, pīlu, śam $\bar{\imath}$ and karīra were growing on the banks of the Sarasvatī.

\footnotetext{
108 See Wealth of India ${ }^{2}$ III/275.

109 See on these lists Misra 1982: 185-187.
} 
Both species of Salvadora, S. persica and S. oleoides, do not need much water and are in particular found in the dry and arid regions of India, on saline lands and in coastal regions just above the high-water mark. ${ }^{110}$ Aegle marmelos (bilva) is found in dry deciduous forests, Balanites aegyptiaca (Linn.) Delile (inguda) in the drier parts of India. Prosopis cineraria (Linn.) Druce (śam $\bar{l})$ also grows in dry and arid regions, as does Capparis decidua (Forsk.) Edgew. (karīra). ${ }^{11}$ The plant community described in the above verse is typical of arid regions, which makes it unlikely that pīlu designates Careya arborea here, a tree occurring sporadically throughout the greater part of India except in very dry areas. ${ }^{112}$

The presence of the described community of trees on the banks of the Sarasvatī is remarkable. This river, now lost in the sands of the desert, flowed on to the sea in ancient times. ${ }^{113}$

(6) MBh 8.30.35-36a $\approx$ MBh (B) 8.44.31cd-33a:

pañca nadyo vahanty etā yatra pīluvanāny api /

śatadruś ca vipāśā ca tritìyerāvat̄̃ tathā |

candrabhāgā vitastā ca sindhușașthā bahirgatāh $/\left.\right|^{114}$

àratța nāma te deśăh ...

Dort, wo die fünf Flüsse fliessen, dort gibt es auch pīlu-Wälder: Śatadru, Vipāśā, als dritte die Irāvatī, Candrabhāgā und Vitastā und als sechstes die Sindhu, hervorgekommen (aus dem Himālaya), dort liegen die Gegenden Āratțā ... (transl. Syed 1990: 444).

Syed's view that these $p \bar{\imath} l u$ forests are composed of Salvadora persica is not convincing in view of the many rivers mentioned in this region. It may well be that Careya arborea is meant, with the proviso that forests of this usually sporadically present tree do exist.

(7) Bṛhatsaṃhitā (BS) 29.11ab:

āmraih kṣemam bhallātakair bhayam pīlubhis tathārogyam /115

Mangos point to safety; Semecarpus to danger; walnuts to healthiness (transl. Kern 1913: I/269).

One should infer the happiness of mankind from mangoes; danger, from Bhallātaka; health, from Pīlu (transl. Bhat 1981: 284).

\footnotetext{
110 Wealth of India ${ }^{1}$ IX/193-194.

111 Van Buitenen translates karīra as "thorns" (1975: 560).

112 Wealth of India ${ }^{2} \mathrm{III} / 274$.

113 See on the Sarasvatī, for example, Murthy 1980.

114 Variants in MBh (B): uta instead of api, tṛtīyairāvat̄, bahir gireh.

115 No remark on pillu is found in Bhattotpala's commentary.
} 
Kern's rendering of pillu as "walnut" is remarkable. He does not mention a source for this identification, but it reminds one of the $p \bar{\imath} l u$ fruits from the North mentioned by Cakrapannidatta in his commentary on the Carakasamhitā. ${ }^{116}$

(8) BS 53.63ab:117

pūrvottarena pīlor yadi valmīko jalam bhavati paścāt /118

If an ant-hill is stationed north-east of a Pìlu-tree, there will be water to the west (transl. Kern 1913: II/32 [54.63ab]).

Ein Ameisenhaufen nordöstlich eines pīlu deutet auf Wasser westlich davon hin (transl. Syed 1990: 444 [54.63ab]).

If there be an ant-hill to north-east of a Pīlu tree, there would be water $\ldots$ to the west of the tree (transl. Bhat 1981: 511 [54.63ab]).

(9) BS 53.65:

pīlor eva prācyām valmīko 'to 'rdhapañcamair hastaih ।

diśi yāmyāyām toyam vaktavyam saptabhih purusaih //

Should the ant-hill stand on the eastern side of the Pilu-tree, then it may be predicted that in a southerly direction there is water, at $7 \mathrm{~m}$. 1., at a distance of four cubits and a half (transl. Kern 1913: II/32 [54.65]).

If the ant-hill be to the east of the Pīlu tree, there would be water 4 cubits and a half to the south at a depth of 35 cubits (transl. Bhat 1981: $512[54.65])$.

(10) BS 53.75:

pīlusametā badarī hastatrayasammite diši prācyām / viṃśatyā puruṣānām aśoṣyam ambho 'tra sakșāram //

On the east side of a jujube combined with a Pīlu, water will be found, never drying, but brackish, at $20 \mathrm{~m}$. l. (transl. Kern 1913: 32 [54.75]).

If the jujube tree is combined with a Pīlu tree, there will be an inexhaustible supply of brackish water 100 cubits below to the east of the tree at a distance of three cubits (transl. Bhat 1981: 514 [54.75]).

116 See Cakrapāṇidatta ad Ca. Sū. 2.4, 27.145ed-146ab; Ka. 7.20cd; Si. 7.63. The pīlu fruits from the North may be those of the walnut tree, Juglans regia Linn., called giripīlu in a number of sources. It has rarely been observed that the pīlu of the Carakasampitā may not be the ordinary tree of that name in all instances where it appears. An awkward point remains: the Carakasaṃhitā and Cakrapāṇi are acquainted with the walnut tree under the name aksota. Cf. further p. 58f. below.

117 See Shastri 1969, Appendix IV: "Dakārgala or the art of exploring under-ground water-springs".

118 Bhattotpala only makes clear that the $p \bar{l} l u$ is a tree; the same applies at 53.65 and 75 . 
The verses on water veins and the other trees mentioned in the same context point to the pĩlu as a desert tree. It may therefore be a Salvadora. Certainty cannot be reached, for the presence of underground water is not a requirement for this tree. Termites, on the other hand, need water and the presence of their buildings (valmik $a$ ) indicates its presence under the surface of the soil.

(11) Śārngadharapaddhati 205:

karabhadayite yat tat pītam sudurlabham ekadā madhu vanagatam tasyālābhe virauși kim utsukī /

kuru paricitaih pīloh pattrair dhṛtim marugocarair jagati sakale kasyāvāptih sukhasya nirantaram //

Weshalb klagst du, Kamelweibchen, voll von Sehnsucht darüber, daß du nicht länger das süsse Wasser, das du im Walde getrunken, erlangen kannst? Gib dich mit den in der Wüstenei allein erreichbaren Blättern des pīlu zufrieden! Wer in der ganzen Welt kann Glück in ununterbrochener Folge geniessen? (transl. Aufrecht 1873: 88f.).

Here the $p \bar{\imath} l u$ is a tree growing in arid regions, which means that it is a Salvadora.

(12) Subhāṣitaratnakoṣa $17.512 \mathrm{~cd}$ :

dattvā pīluśamīkarīrakavalān svenāñcalenādarād àmrsțam karabhasya keśarasațābhārāvalagnam rajah /|

Liebevoll rieb sie (die Gattin) den dick anhaftenden Staub von dem Mähnenhaar des Kamels mit dem Saume ihres eigenen Gewandes ab, nachdem sie ihm einige Händevoll pīlu, śamı̄ and karīra gereicht hatte (transl. Syed 1990: 443).

[Her husband has returned across the trackless desert; the mistress of the household looks upon his face with eyes unsteady from her tears of joy.]

She offers to his camel palm and thornleaf and from its mane wipes the heavy dust

with the hem of her own garment, tenderly (transl. Ingalls 1965: 187).

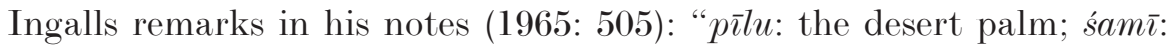
the thorny Prosopis spicigera; ... karīra: the common desert thorn". The śam̄, Prosopis cineraria (Linn.) Druce $=$ P. spicigera Linn., is indeed a tree with branches bearing conical spines; it is found in dry and arid regions of India. The karīra, Capparis decidua (Forsk.) Edgew., is not thorny; it is a shrub or small tree with scanty small leaves found only on young shoots. It may be that Ingalls had Capparis spinosa Linn. in mind, the leaves of which are relished by sheep and goats. The reasons 
for the interpretation of $p \bar{\imath} l u$ as a desert palm are completely obscure to me.

The leaves of $p \bar{\imath} l u$, śamī, i.e., Prosopis cineraria (Linn.) Druce = P. spicigera Linn., and karīra, i.e., Capparis decidua (Forsk.) Edgew., are suitable as camel fodder. Both Salvadora persica and Careya arborea can be the $p \bar{\imath} l u$ of this verse.

(13) Manusmṛti 2.45:

brāhmaṇo bailvapālāśau kṣatriyo vātakhādirau /

pailavaudumbarau vaiśyo daṇ̂̄àn arhanti dharmatah //

The staff of a vaiśya Vedic student should be of pillu or udumbara wood.

(14) Vāsiṣthadharmasūtra 11.54:

... audumbaro vā vaiśyasya

... and a Vaiśya's [staff should be] of udumbara wood (transl. Olivelle 1999: 279). ${ }^{119}$

(15) Gautamadharmasūtra 1.22-23:

bailvapālāśau brāhmaṇadaṇdau. āśvatthapailavau śeṣe.

A Brahmin's staff is made of wood-apple or Palāśa wood, and those of the other two of banyan and Pīlu wood, respectively (transl. Olivelle 1999: 79$){ }^{120}$

(16) VS 61.4:

na ca kovidāraśamīpīlupippalèngudaguggulujam

(A householder must not use for cleaning his teeth) ... nor (the twigs of) the kovidāra (yugapattraka), śamī, pīlu (gudaphala), pippala (holy figtree), inguda, or guggula trees ... (transl. Jolly 1880: 197). ${ }^{121}$

\footnotetext{
119 The $p \bar{\imath} l u$ is omitted.

120 The Āpastambadharmasūtra (1.2.38) does not mention the pīlu, the Baudhāyanadharmasūtra (1.3.15) does not specify any tree. See Bühler's note on his translation of Manusmṛti II.45 (1886: 38) for more parallels.

121 The rules about trees and other plants suitable for making toothsticks vary. The VS recommends the banyan, asana, arka, khadira, karañja, badara, sarja $(=s \bar{a} l a)$, nimba, arimeda, apāmārga, mālat̄, kakubha, and bilva (VS 61.15). Ca. Sū. 5.73ed-74ab recommends karañja, karavīra, arka, mālatī, kakubha, and asana. A.s. Sū. 3.12ed-13ab enumerates as suitable vața, asana, arka, khadira, karañja, karavīra, sarja, arimeda, apāmārga, mālati, and kakubha.
} 
The ban on the pīlu has not yet been elucidated and is remarkable because this tree in particular is used for making toothsticks over a very wide area of Asia and Africa. Syed observes:

Das Verbot war nötig, um den Baum zu schützen, wurde er doch für zu wertvoll angesehen, um ihn ständiger Plünderung zu überlassen. ${ }^{122}$

She does not explain why the pillu was regarded as valuable; it is questionable whether this was actually the case. Syed adds in a footnote:

Auffallend ist, daß die Zweiglein all derjenigen Bäume nicht als Zahnstocher verwendet werden durften, die gutes, zur Herstellung von Möbeln, Götterbildern etc. brauchbares Holz lieferten. Diese wertvollen Bäume sollten unversehrt bleiben, das tägliche Abbrechen von vielen Zweiglein hätte ihnen geschadet. ${ }^{123}$

\section{The Arthaśástra: Pīllu and Some Other Plants and Animals}

An important source mentioning pīlu a number of times in an unusual context has still to be examined in order to investigate which kind of tree may be meant. This treatise is the famous Kauțilīya Arthaśāstra (AŚ). To that purpose the relevant passages will be studied in detail.

(1) The first passage is AŚ 2.12.8, where pīlu forms part of a number of plant materials and other substances employed in the extraction of metals from their ores. The identity of this pillu is not easy to determine. P. Sensarma regards it is Careya arborea. ${ }^{124}$ The wood of that tree is said to be a moderately good fuelwood; that of Salvadora oleoides and Salvadora persica is not a good fuel. Another tree may be meant here. The wood of Strychnos nux-vomica is close-grained, hard and heavy.

Gaṇapati Śāstrī remarks in his ŚŚñmūla $(\dot{S} M)$ that pīlu is the tree called gudaphala $(\mathrm{I} / 202,2)$. This name, though absent from the early medical classics, is simply a rather common synonym of Salvadora persica, probably because its fruits are sweet.

(2) The second passage from the same chapter is AŚ 2.12.9, where the ashes (kșarra) of the pīlu are said to give softness (mārdava) to the metal extracted.

\footnotetext{
122 Syed 1990: 446.

123 Syed 1990: 446, n. 2.

124 Sensarma 1998: 50.
} 
(3) AŚ 13.1.16:

pīluvikhādanena karakayoștryā gardabhīkṣ̄rābhimanthaneneti dhruvopakārina iti.

ŚM (III/183):

p̄̄lvityādi.dhruvāpakāriṇo ye parasya nityāpakartāras tān, p̄̄luvikhādanena pīluṿ̣kṣaviśeșaphalam tiktarasam tasya vikhādanena bhakṣanena - yathā pīlubhakṣanam tiktarasatvād udvejakam tadvat parasevanam iti kathanene-

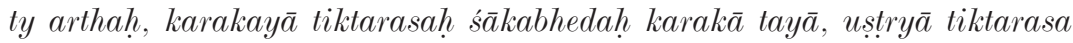
oṣadhibheda uștrī tayā tābhyām saha param udvejakatvena dharmenopamāyety arthah, gardabhīkșīābhimanthanena paropasarpanasya tatsamānatvakathanenety arthah.

J.J. Meyer (1926: 615):

[...] die, die beständige Dienste erwiesen haben, (sollen aufgestachelt werden) mit dem "Zerkauen der Pīlufrucht", dem "Wasserkrug", dem "weiblichen Kamel" und dem "Buttern der Milch einer Eselin".

Kangle (1972: 476):

(He should stir up) ... those who constantly oblige, by the eating of the $p \bar{l} l u$-fruit, the hail, the female camel and churning of the she-donkey's milk.

Shamasastry (1960: 425):

(They should characterise the enemy) as eating a piece of the wood of pīlu (Careya-Arboreo), or as churning the milk of a she-camel or a shedonkey (for butter) to those who are rendering to him valuable help.

This is a difficult passage from the chapter on "Instigation to Sedition". The word dhruvopakarinah is an emendation suggested by J.J. Meyer (1926: 615, n. 2) and adopted by Shamasastry and Kangle. The manuscripts have dhruvāpakārinah, "constantly doing harm", a reading adopted by Gaṇapati Śāstrī. For my part, I am not sure that the correction is necessary.

The pìlu meant here cannot be Careya arborea or a Salvadora. The fruits of these trees are not bitter; Salvadora fruits are even sweet. They do not constitute a source of trouble and are unsuitable for stirring up people to whatever action. They do not belong to edibles called khädya, which need chewing.

J.J. Meyer remarks in a footnote (loc. cit.):

Die Frucht des pīlu, d.h. der Careyya arborea dient zum Fettmachen von Tieren $^{125}$ und wird, wie es scheint, zerkaut und weggespuckt. Oder dient Pīluholz besonders zur Reinigung der Zähne? Solches Holz wird nach

12.5 See MBh 2.47.4, already dealt with above, p. 35. 
dem Gebrauch als magisch gefährlich sorgfältig weggetan. Der Wasserkrug endet als verachteter Scherben, einerlei wie viel des erquickenden Segens er getragen hat, und das Kamel wird nur tüchtig ausgenutzt und schlecht behandelt. Die Butterung der Eselsmilch führt zu keinem Ergebnis, ebensowenig der Dienst bei solch einem Landesherrn.

Kangle explains in a note (Kangle 1972: 476):

$p \bar{\imath} l u$ is a kind of fruit which apparently provides no nourishment, but is only a source of trouble; so is upakāra conferred on this king.

This interpretation is completely wrong.

The other items are also hard to interpret. Kangle comments (loc. cit.):

karak $\bar{a}$ "hail" is understood as a kind of bitter vegetable in Cs, as a waterjug by Meyer. A hail-stone may signify harmfulness or uselessness. ustryā: this also is a kind of bitter plant according to Cs. One may understand the female camel as being useless for purposes of milk. gardabhī- etc. apparently signifies great effort with no return.

Gaṇapati Śāstrī remarks on pillu that the fruit of a particular tree is meant with a bitter taste, without specifying which tree he has in mind. ${ }^{126}$ Neither Salvadora persica and oleoides nor Careya arborea bear such fruits, which makes Ganapati's interpretation hard to understand. The extremely bitter seeds of Strychnos nux-vomica, however, may be intended, which makes this passage of the Arthaśāstra of great significance for a solution of the question raised in this investigation.

Kangle's suggestion about karak $\bar{a}$ as identical with a bitter vegetable mentioned in the Carakasamhitā is unintelligible, for karakā as a plant name is absent from that treatise. The word karaka may mean a watervessel, as Meyer takes it, but the dictionaries indicate that it also denotes various plants, ${ }^{127}$ while another karaka means tax or tribute. The text, however, does not mention karaka but karaka, unknown as a plant name.

Kangle's remark about uștrī as referring to a bitter vegetable mentioned in the Carakasamhitā has no basis. The word is absent from that text in this sense. ${ }^{128}$ Compounds with ustra as the first member are not rare at

126 Cf. the quotation from the Śrimmūlā above, p. 41.

${ }^{127} P W$ and $M W$ (valid names added): Bauhinia variegata Linn., Butea monosperma (Lam.) Taub. = Butea frondosa Koenig ex Roxb., Capparis decidua (Forsk.) Edgew. = Capparis aphylla Roth, Mimusops elengi Linn., Pongamia pinnata (Linn.) Pierre = Pongamia glabra Vent. = Derris indica (Lam.) Bennet, and Punica granatum Linn.

$128 P W$ does not give ustrti as a plant name. It is a plant name found in a nighantu according to $M W$. 
all as plant names, but I have not come across an uṣtrī so far. The name uṣtrik $\bar{a}$, however, as well as karabha , are synonyms of $v r s s c i k \bar{a} l \bar{\imath},{ }^{129}$ a plant described as bitter and found in all three works forming the Brhattrayī. It is variously identified as Pergularia daemia (Forsk.) Choiv. = Pergularia extensa (Jacq.) N.E.Br. = Daemia extensa R.Br. = Asclepias daemia Forsk., Tragia involucrata Linn. and Girardinia diversifolia (Link) Fries = Girardinia heterophylla Decne. = Urtica diversifolia Link.

Shamasastry omits karak $\bar{a}$ in his translation and is of the opinion that $p \bar{\imath} l u$ wood is intended.

(4) AŚ 14.1.15:

śārikākapotabakabalākāleṇdam arkākṣip̄̄lukasnuhikṣ̄rapiștam andhīkaranam añjanam udakadūṣaṇam ca.

ŚM (III/216):

tatra śārikā gorāṭ̄, bakah kahvah, balākā bisakanthikā. arko 'rkaparṇākhyaușadhih, akș̄ vṛkṣabhedo vibhītakaprakārah, snuhih samantadugdhā.

J.J. Meyer (1926: 641):

Mist der Predigerkrähe, der Taube, des Reihers und des Kranichs, zusammengeknetet (pishta) mit Calotropis gigantea, akshi, pīluka und der Milch der Euphorbia antiquorum gibt eine Augensalbe, die blind macht, und ein Mittel, das Wasser zu vergiften.

Kangle (1972: 496):

The dung of the śarike, the pigeon, the heron and the crane, kneaded with the milk of arka, akși, pilluka and snuhi plants is a blinding eye-salve and a polluter of water.

Shamasastry (1960: 443):

The ointment prepared by mixing the excretion of sārikā (maina), kapota (pigeon), baka (crane), and balākā (a kind of small crane), with the milk of mañkāshī (hyperanthera morunga), ${ }^{130}$ pīluka (a species of careya arborea) and snuhi (euphorbia), causes blindness and poisons water.

The Hindī translation of Vāchaspati Gairola (Gairola 1962: 906-907) has the same as Kangle.

129 RN 9.7-9.

130 Hyperanthera moringa Vahl is (according to Hooker 1875-1897) a no longer valid name for Moringa oleifera Lam., which has no latex. 
Gaṇapati Śāstrī interprets arka as a plant called arkaparṇa or arkaparṇā, which names are not recorded. ${ }^{131}$ Furthermore, he is obviously of the opinion that aksi is related to the tree called akṣa or vibhitaka, Terminalia bellirica (Gaertn.) Roxb. (a tree without a latex), but this idiosyncratic view is found nowhere else. The author of the Śsimūla does not identify pīluka.

J.J. Meyer interprets arka as Calotropis gigantea (Linn.) R.Br. ex Ait.f., but Calotropis procera (Ait.) Ait.f. is also employed as arka. ${ }^{132} \mathrm{He}$ connects kșira with snuhi only. His identification of this plant as Euphorbia antiquorum Linn. is too specific; several species of Euphorbia possessing a milky sap are used as snuhi. ${ }^{133}$

Meyer remarks in a footnote (1926: 641, n. 3):

Statt à̉ka setze ich auch hier arka. Für das folgende akshīpīluka möchte man akshībapīluka vermuten, da ja in dem vorhergehenden Augengiftmittel [see AŚ 14.1.13] akshība ${ }^{134}$ und pīluka ebenfalls nebeneinander vorkommen. Aber akshi kehrt dann in den Zeilen 10 und 19 ebenfalls vor pīluka and 411, 9 vor gulgulu wieder. So wird wahrscheinlich akshi "Auge" der Name einer besonderen Pflanze sein.

Kangle (ef. his translation quoted above) assumes that akṣi and pīluka are plants with a milky sap; whatever akși may be, $p \bar{l} l u(k a)$ (Salvadora sp.) is without a latex. Unfortunately, Kangle gives no footnotes.

Shamasastry is wrong in regarding Careya arborea as a tree with a milky sap. He seems to leave out arka in his translation.

The major problem with this passage is the interpretation of akșipiluka, a word occurring three times in chapter thirteen. The solution of Kangle and Gaṇapati Śāstrī cannot be the right one: a plant called akṣi is unknown and $p \bar{\imath} l u$ is not poisonous. Therefore I propose an emendation: $d a$ instead of $l u$; these akșaras resemble each other in the script of the manuscripts of the Arthaśāstra. The correct reading must be akșipĩ daka, the name of a plant of disputed identity, found twice in the chapter

$131 P W$ and $M W$ regard arkaparna and arkapatra as arka or its leaf, and arkapatrā as Aristolochia indica Linn. A plant called arkaparñ $\bar{\imath}$ of unknown identity, occurs in the Suśrutasaṃhitā (Ka. 8.106).

132 Meyer obviously follows $P W$ and $M W$ which only mention Calotropis gigantea.

133 Used as snuhi are Euphorbia neriifolia Linn., Euphorbia nivulia Buch.-Ham. and Euphorbia royleana Boiss.; see Abdul Kareem 1997: 61f.

134 Not identified by J.J. Meyer. The Carakasamhitā mentions akșiva twice: Sū. $4.11(15)$ as a member of the krimighna group of ten drugs (Cakrapāni remarks: either abdaka or śbhāñjana) and Ci. 3.267 (not the same as śbhāñjana, which is separately mentioned in the same recipe). 
concerned with poisoning of the Carakasaṃhitā (Ci. 23), in the vicinity of vāyasapiluka.

This plant is known under a series of related names: akșapida, ${ }^{135} a k s a$ -

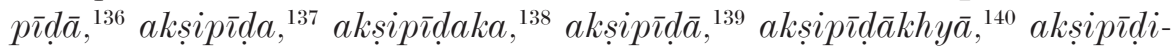
$k a,{ }^{141}$ and aksipipdikā. ${ }^{142}$

A number of authorities regard aksipīda as a synonym of yavatikta ${ }^{143}$ variously identified as Andrographis paniculata (Burm.f.) Wall. ex Nees, Canscora decussata Schult. et Schult.f., Centaurium roxburghii (G.Don) Druce, and Ipomoea grandiflora Roxb. Several sources consider yavatiktā to be a synonym of śankhin̄ or interpret aksip̄̄da as saikhin̄̄. ${ }^{144}$ This brings no relief because the identity of śákhin̄ is very controversial. It is identified as Canscora decussata Schult. et Schult.f., Clitoria ternatea Linn., Ctenolepis cerasiformis Naud., Euphorbia dracunculoides Lam., and Mukia maderaspatana (Linn.) M.Roem.

An unequivocal identification cannot be reached.

arka yields a milky juice, as does snuht. It may be for that reason that Avadheś Nārāyaṇ Siṃha, in his book on the plants of the Arthaśāstra, identifies akși as an Euphorbia, namely Euphorbia dracunculoides Linn., though this plant is more commonly called saptal $\bar{a}$ and is not known for its latex, in contradistinction to many kinds of Euphorbia. ${ }^{145} \mathrm{He}$ remains with the problem that the tree mentioned as $p \bar{\imath} l u$ does not possess a latex.

(5) AŚ 14.1.17:

karavīrākṣip̄̄lukārkamṛamāran̄inogo madanakodravakvāthayukto hastikarṇapalāśayukto vā madanayogah.

ŚM (III/217):

mrgamārany oṣadhibhedah.

\footnotetext{
${ }_{135}$ Su. Ci. 9.48; Paryāyaratnamālā 113.

136 DhN 1.256; RN 3.380f..

137 Ca. Ci. 23.216; Tantrasārasamgraha 10.16 and 44.

138 Ca. Ci. 23.215 and Ka. 11.3.

139 NŚ 276cd: nākul̄ = akșipīdō; SN nāmasamgraha 259.

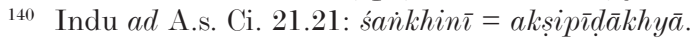

141 Șaḍrasanighaṇtu 4.94.

142 Madanapālanighaṇṭu 2.15; Abhidhānamañjarī 51.

143 Cakrapāṇidatta ad Ca. Ka. 11.3; Ḍalhaṇa ad Su. Ci. 9.48; Șaḍrasanighaṇṭu 4.94; SN nāmasamgraha 259; DhN 1.256; RN 3.380f.

144 Șaḍrasanighaṇțu 4.94; SN nāmasamgraha 259.

145 Simha 1989: 3-5.
} 
J.J. Meyer (1926: 642):

[...] eine Mischung von Oleander, akshi, pīluka (Careya arborea), arka (Calotropis gigantea) und mrigamāraṇ̄ ("Wildtöterin", "Gazellentöterin"), gemischt mit einem Absud von madanakodrava oder gemischt mit einem Absud von "Elefantenohr" und Curcuma zedoaria, gibt madanayoga (Betäubungsmixtur).

Kangle (1972: 496):

[...] a mixture of karavìra, akși, pīluka, arka and mrgamārañi, mixed with a decoction of madana and kodrava, or mixed with a decoction of hastikarna and palāsa is a stupefying preparation.

Shamasastry (1960: 443):

(The mixture of) the powder of karavīra (oleander), akshipīluka (careya arborea), arka plant, and mrgamāraṇi (?), combined with the decoction of madana and kodrava or with that of hastikarṇa and palāśa, is termed madana mixture (madanayoga).

Sensarma (1998: 87):

When karavīa (Nerium indicum Mill.), akși (Elaeocarpus ganitrus Roxb.?), pīluka (Careya arborea Roxb.), arka (Calotropis gigantea [L.] R.Br. ex Ait.), and mrgamārañ̄ (some monocarpic plant) are mixed with the decoction of madana (Xeromphis spinosa [Thunb.] Keay) and kodrava (Paspalum scrobiculatum L.) or with that of hastikarna (Ricinus communis L.) and palāśa (Butea monosperma [Lam.] Kuntz), a type of madanayoga is made. This can cause psychological disorder.

Meyer is right in considering karavira as the oleander, Nerium oleander Linn. Sensarma's Nerium indicum Mill. is an invalid synonym of the same shrub. According to my above suggestion (cf. p. 44) the plant called akșipz̃daka is mentioned here again, which means that pilu is absent.

The identity of the plant called mrgamārañ is unknown. Its name suggests a poison used by hunters. It would be attractive to see here at last a name for the poison tree, Antiaris toxicaria, but the female form of the word indicates that it probably designates a herb. The remark of Sensarma that a monocarpic plant is meant is only a guess.

Meyer remarks rightly in a footnote on "Elefantenohr" und Curcuma zedoaria (1926: 642, n. 3): "oder hastikarnapalāça als ein Wort: Butea frondosa, deren Saft den bengalischen Kino liefert".

Sensarma is of the opinion that akși denotes Elaeocarpus sphaericus (Gaertn.) K.Schum. = Elaeocarpus ganitrus Roxb.; however, the stones of the fruits of this tree are commonly called rudrākșa, never akși. 
It is indeed erroneous to split up hastikarnapalāsa $a^{146}$ into hastikarna and palāśa. A plant called hastikarṇa without a following palāśa is absent from the Arthaśāstra, while hastikarnapalāsa is found several times in post-classical medical treatises. ${ }^{147}$ P.V. Sharma identifies it as Butea superba Roxb., others as Leea macrophylla Roxb. ex Hornem. The plant called hastikarna occurs in the classical medical treatises ${ }^{148}$ and is also identified as Butea superba by P.V. Sharma and as Leea macrophylla by Balwant Singh and Chunekar. P. Sensarma is the only one to consider hastikarna to be a name of Ricinus communis Linn., probably borrowing this identification from Bāpālāl Vaidya's Nighaṇtu ādarśa (Bāpālāl Vaidya 1985). Butea monosperma (Lam.) Taub., palāśa, is consistently called Butea monosperma (Lam.) Kuntz. by this author.

Is the described mixture stupefying (a madanayoga) indeed? Poisonous ingredients are karavira and arka. The seeds of Butea superba are used as a sedative and its roots contain a poisonous substance. Leea macrophylla, on the other hand, is not toxic at all; the leaves and fruits are eaten and the roots are medicinal.

hastikarnapalāśa is also found at AŚ 14.1.9:

śatakardamoccidingakaravīrakatutumbīmatsyadhūmo madanakodravapalālena hastikarnapalāsapalālena vā pravātānuvāte prañ̄te yāvac carati tāvan mārayati.

\section{J.J. Meyer (1926: 639):}

Soweit der Rauch von "Hundertdreck", (dem giftigen Wassertier) uccidinga, dem Oleander, der bitteren Flaschengurke und von Fisch, wenn (sie alle zusammen) mit dem Stroh von madanakodrava oder den Stengeln von "Elefantenrohr (sic)" (N. verschiedener Pflanzen) und Curcuma zedoaria verbrannt (werden), mit dem Luftzug dahinwehend, fortgeführt wird, tötet er (was er trifft).

Kangle (1972: 495):

The smoke of śatakardama, uccidinga, karavira, the bitter gourd and fish, with the stalks of madana and kodrava or with the stalks of hastikarna and palāsa, when carried forth in a breeze blowing forward, kills everything to which it blows.

146 A correct interpretation of the compound is found in Simha 1989: 473-476. See on the plant: Bāpāāal Vaidya 1982: 89-91; Sharma 1985: 354f.; Singh - Singh 1981.

147 Kāśyapasaṃhitā Khila 17.90 (interpreted by Hemarāja Śarmā as bhūpalāśa); Cakrapāṇidatta's Cikitsāsaṃgraha (1933), galagaṇda 2; Vidyāpati's Vaidyarahasya, gaṇda$m \bar{a} \bar{a}$ 12; Ṭoḍarānanda's Āyurvedasaukhya 6.15.28.

148 Su. Sū. 39.9 and 45.115; A.h. (1939) Ci. 17.27. 
Shamasastry (1960: 442):

The smoke caused by burning the powder of satakardama (?), uchchidinga (crab), karavīra (nerium odorum), katutumbi (a kind of bitter gourd), and fish, together with chaff of the grains of madana (?) and kodrava (paspalum scrobiculatum), or with the chaff of the seeds of hastikarna (castor oil tree) and palāśa (butea frondosa) destroys animal life as far as it is carried off by the wind.

Sensarma (1998: 90):

The powder of śata (Asparagus racemosus Willd.), kardama, karavīra (Nerium indicum Mill.), katutumbi (a kind of bitter Lagenaria siceraria [Mol.] Standl.), uccidinga (Cancer pagurus), and fish, together with the chaff of the grains of madana (Xeromphis spinosa [Thunb.] Keay) and kodrava (Paspalum scrobiculatum L.), or with the chaff of the seeds of hastikarna (Ricinus communis L.) and palāśa (Butea monosperma [Lam.] Kuntz) this smoke destroys animal life as far as it is carried off by the wind.

Sensarma is the only author to split śatakardama into śata and kardama, groundlessly assuming śata to be an abbreviation of śatāvarī and not knowing how to interpret kardama. Meyer remarks in a footnote (1926: 639, n. 7) that satakardama is the name of an animal living in the mud. He regards uccidinga, in agreement with the standard dictionaries, as an aquatic animal. The small invertebrate animal called uccidinga $(k a)$ is also mentioned at AŚ 14.1.4. The symptoms of an uccitinga bite are described in the Carakasamhitā. ${ }^{149}$ Caraka regards it as vāta-provoking; the treatment for the bite is like that for a scorpion sting. ${ }^{150}$ The Gulabkunverba team (Ca. [1941]), as well as R.K. Sharma and Bhagwan Dash (Ca. [1997]), regard it, for whatever reason, as a poisonous crab; Sensarma considers it to be the crab called Cancer pagurus which species is, however, an inhabitant of the North Sea, North Atlantic and Mediterranean. ${ }^{151}$ P.V. Sharma (Ca. [1983a]) leaves the word as it stands. The fact that the uccitinga appears to be closely related to scorpions in the Carakasaṃitā makes it probable that it is a similar animal, not a crab, and not even aquatic at all. The same uccitinga is found in the Suśrutasamphitā, where it is classified as a vāyavya type of kīta that, as implied by the name of the type, excites vāta, ${ }^{152}$ but is not associated with water at all. The uccitinga is also known to the Aṣtāngasamgraha

149 Ca. Ci. 23.153.

150 Ca. Ci. 23.165, 172 and 174.

151 The meaning "crab" is found in $P W$ and $M W$ and based on some indigenous lexica; these dictionaries may be the sources of the interpretation. It is questionable that poisonous crabs occur in India. Wealth of India ${ }^{1}$ (II/363-365) only records a number of edible crabs.

152 Su. Ka. 8.5-8ab. 
as one of the vāyavya kițas. ${ }^{153}$ This source adds ${ }^{154}$ that it bites very painfully (abhyadhikavyatha) with its mouth parts. The commentator Indu (ad A.s. U. 43.36) remarks that the Mañjarī describes it as a thin, long and elevated (ucca) scorpion. The genus and species cannot be determined from this description. The most dreaded poisonous scorpions of India belong to the genera Buthus and Heterometrus, the red and the black scorpions. The poison of Buthus tamulus Fabr. is particularly virulent and sometimes fatal to children.

Kangle refrains from explaining śatakardama and splits two compounds which actually form one item each: madanakodrava and hastikarnapa$l \bar{a} s ́ a$.

Gaṇapati Śāstrī does the same (ŚM III/214f.): tatra kardamo yaksakardamah, karavīro hayamārākhya ${ }^{155}$ oṣdhibhedah, katutumbī ikșvāku, ${ }^{156}$ mada$n o^{157}$ dhustūrah, kodravo dhānyabhedah, hastikarnah kustumburuh, ${ }^{158}$ palāśah kaccoram. ${ }^{159}$

Kangle, Ganapati Śāstrī and Sensarma split madanakodrava into two items, madana and kodrava. Kangle refrains from identifying madana, while Ganapati regards it as dhustūra, a species of Datura, a genus of poisonous plants. Sensarma considers it to be Catunaregam spinosa (Thunb.) Tiruv. $=$ Xeromphis spinosa (Thunb.) Keay $=$ Gardenia spinosa Thunb. The second member, kodrava, designates the grass Paspalum scrobiculatum Linn., from which the grain called kodo millet is obtained. The Arthaśāstra refers to kodrava also at 2.15.25 and $34^{160}$ and 2.24.12. ${ }^{161}$ A wild (vanakodrava) and a cultivated form are known. kodrava and its synonym koradūsa are frequently mentioned in medical texts, while

153 A.s. U. 43.3 f.

154 A.s. U. 43.36 .

155 hayamāra is indeed one of the synonyms of karavina, but two other plants are also called thus: Cascabela thevetia (Linn.) Lippold = Thevetia neriifolia Juss. ex Steudel and Wrightia tinctoria (Roxb.) R.Br. (see Abdul Kareem 1997: 31 and 147).

156 These two names belong to Lagenaria siceraria (Molina) Standley = Lagenaria vulgaris Ser.

157 The most usual identification of madana is Catunaregam spinosa (Thunb.) Tirvengadum $=$ Randia dumetorum (Retz.) Poir., a non-toxic plant; its fruit pulp is an excellent emetic.

158 This is a name commonly applied to Coriandrum sativum Linn.; this identification of hastikarna is absent from $P W$ and $M W$.

159 This plant (kacchora in $P W$, kacora in $M W$ ) is a species of Curcuma $(P W)$ or, more specifically, Curcuma zerumbet Roxb. $(M W)$, an old name for Curcuma zedoaria Roscoe. Ganapati's remark that palāśa is the same as kaccora may derive from the Amarakośa (4.155a: karcūro 'pi palāso 'tha).

160 Information on the changes in the amount of pounded and boiled kodrava.

161 At AŚ 2.24.12 kodrava belongs to the group of crops to be sown first. 
madanakodrava is rather uncommon. The name occurs once in the Suśrutasaṃitā (Ci. 17.37). It is interesting to see that Dalhana, though interpreting the word correctly himself, ${ }^{162}$ adds that others explain it as meaning madana and kodrava ${ }^{163}$ which makes it less remarkable that this still happens with modern authors. Those doing so are faced with a toxic madana. Ganapati takes it as a synonym of dhustura in this case, which is unusual but not impossible. dhustūra and dhattūra are names for poisonous Datura species. If Ganapati had taken a look at the Suśruta passage referred to he would have seen that the seeds of dhattura and madanakodrava are mentioned together. The solution is easy: the grain of Paspalum scrobiculatum is poisonous in general, though nonpoisonous types have also been reported. The toxic principle is located to a great extent in the husk, the outer coat of the grain. After harvesting, the grain is therefore dried in the sun and then husked. It should be stored for six months before being used as food, as immature or newly gathered grains are poisonous. The chief symptoms of poisoning are unconsciousness or delirium, tremors of the voluntary muscles, vomiting, and difficulty in swallowing. ${ }^{164}$

The remark that kardama is the same as yaksakardama and the omission of śata are not helpful. Kangle mentions in a confusing footnote (Kangle 1972: 495, note on AŚ 14.1.9) that the Śrīmūla understands śata and kardama as two plants. Actually, yaksakardama is not a plant, but a fragrant compound; its ingredients are enumerated in the Amarakośa (2.6.133ab), Paryāyaratnamālā (1721-1723), Bhoja's Cārucaryā (p. 293) and the Yogaratnākara (p. 99). The word satakardama itself is absent from the standard dictionaries. Certainty about its identity with yakșakardama cannot be reached.

Shamasastry is not acquainted with śatakardama. He identifies karavīra as Nerium odorum Sol., an old name of Nerium oleander Linn. He also splits the compound madanakodrava and adds a question mark to madana without giving a botanical equivalent. His identification of hastikarna as the castor oil tree, Ricinus communis Linn., agrees with one of the options of the standard dictionaries. ${ }^{165}$

\footnotetext{
${ }_{162}$ madotpādakāh kodravā madanakodravāh (p. 269a,24).

163 anye tu vyākhyānayanti - madanam kodravajam bījam ceti (p. 469a,24f.).

164 The Rājatarangin̄i (8.2595f.) refers to the eating of kodrava as a food that is not without bad consequences: "Even greater misery befell Lothana and Vigraha $[r \overline{a j a}]$.... They ate cakes made of oats and Kodrava in husks and the like, and their bodies and clothes became discoloured by dirt" (transl. Stein 1900: II/204).

165 The DhN (1.295f.) and RN (8.445f.) mention hastikarna as one of the names of the red type of Ricinus communis (raktairanda), not of the type with green leaves.
} 
(6) AŚ 14.1.23:

mātṛvāhakāñjalikārapracalākabhekākṣipīlukayogo viṣūcikākarah.

ŚM (III/217):

mātṛāhakah pakṣibhedah, añjalikāra oṣadhibhedah, pracalākabhekākṣipīlukā vyākhyātāḥ.

J.J. Meyer (1926: 642):

Eine Mischung von Fledermaus, añjalikāra, dem Giftreptil pracalāka, Frosch, akshi und piluka (Careya arborea) bewirkt Cholera.

Kangle (1972: 497):

A mixture of mātrvāhaka, añjalikāra, pracalāka, the frog, akṣi and pīluka causes cholera.

Shamasastry (1960: 444):

The mixture of the powder of mātṛvāhaka (?), jalūka (leech), the tail of a peacock, the eyes of a frog, and piluka (careya arborea), causes the disease known as vishūchikā.

Gairola's Hindī translation (Gairola 1962: 908) is similar to that of Kangle.

J.J. Meyer remarks in a footnote on añjalikāra (1926: 642, n. 6):

"An der Stirn zusammengelegte Hände machend", etwa: der "Beter", der "Andächtige", wohl Name eines Tierchens. Oder ist es = añjalikārikā

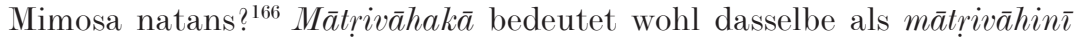
Fledermaus.

Shamasastry takes bhekākși as one word, meaning the eyes of a frog. Gaṇapati Śāstrī refers to his preceding explanations of pracalāka, akṣi and piluka.

Here again akṣipịtaka (cf. above p. 45) may be mentioned.

The item called mātrvāhaka is a problem to the translators and the commentator. The term is, however, not absent from some medical treatises. Sodhala mentions it in his Gadanigraha, in the chapter on yonigā dhīkarana (kaumāra 9.4). ${ }^{167}$ Cakrapāṇidatta's Cikitsāsaṃraha (1933) refers to a

166 This may be the plant now called Mimosa pudica Linn.

167 Gadanigraha 9.4: mātṛāhakacūrnena bhagam ālepayet sad̄̄ / maithunāni niṣeveta punah kanyā bhavisyati //. The Hindī translator, Indradeva Tripāthī, remarks in a foot-

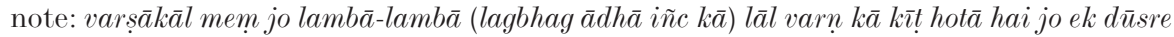

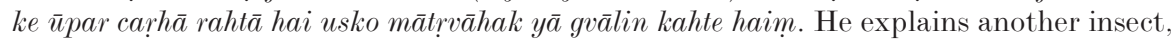
called vrsagopa, mentioned at Gadanigraha 9.7, as also indicating a gvālin. 
mātrvāhakakīta (galaganda 37). ${ }^{168}$ Ṭodara's mātrmāhukīkīta (Āyurvedasaukhya 6.15.71) may have the same meaning. The kìta called vāhaka, mentioned in the Suśrutasaṃhitā and the Aștānngasaṃgraha as a very dangerous one, of an agni nature, exciting all the three dosas, and with a life-threatening (prānanāśana) bite, is probably related to the mātrvāhaka. Jain literature is also acquainted with this animal. The Uttarādhyayana (36.129) mentions it as māivāhaya in a list of beings with two organs of sense. Jacobi remarks in a footnote to his translation (1895: 219 , n. 3) that, according to the description of the "Avakûri" (?), the larvae of the Phryganeae ${ }^{169}$ seem intended, and that, according to the Jīvavicāravṛtti, they are called $c \bar{u} d e l \bar{\imath}$ in Gujarātī. ${ }^{170}$

The item called añjalikāra is not known as the name of an animal or plant, but añjalikarike is frequent as a plant name. The secondary literature rather often identifies it as Mimosa pudica Linn., which cannot be correct since this plant is a native of tropical America, naturalized in India after the arrival of the Portuguese. $M W$ regards it as Mimosa natans Roxb., a no longer valid name for Neptunia oleracea Lour. A frequent synonym of añjalikārik $\bar{a}$ is lajjālu. The latter is identified as another sensitive plant, Biophytum sensitivum (Linn.) DC.

The word pracalāka occurs at two other places in the Arthaśāstra: 14.1.14, and 14.3.16. The Śs̄mūulā explains it as meaning mayūrabarha (III/216), the tail-feather(s) of a peacock, as does Shamasastry, while J.J. Meyer regards it as a poisonous reptile. These differences are based on what one finds in the dictionaries. ${ }^{171}$

The Suśrutasaṃhitā is acquainted with a kaphanimittaja kìta (an insect or some other small invertebrate) called pracalaka (Ka. 8.13) and pracalā$k a$ (Ka. 3.5) that possesses a damstrtā and nakha poison. The pracalāka

168 granthyarbudādijil lepo mātṛāhakakītajah. Sivadāsasena explains: sukhāsāadibhavapadakīta iti khyātah. Niścalakara remarks in his Ratnaprabhā on the Cikitsāsaṃgraha (1933) (galagaṇda 46): surasādibūjabhavah pardakīta iti khyātah (variant reading for būja: vrksa $)$.

169 The familiy of the caddisflies, the Phryganeidae, belongs to the insect order Trichoptera.

170 On the Jīvaviyāra of Śāntisūri see Winternitz 1920: 354. The text has been edited, translated and annotated by Guérinot (1902). Verse 15 mentions the māivāha as an organism with two sense organs; the commentator Ratna, pupil of Meghanandana, remarks that this animal is well known in Gujarat.

${ }_{171} P W$ s.v. pracalaka: a poisonous worm-like animal; s.v. pracalāka: peacock's tail, snake, another poisonous animal. $M W$ s.v. pracalaka: "a venomous reptile"; s.v. pracalāka: "a peacock's tail or crest, a chameleon, a snake or other venomous animal". Kșīrasvāmin ad Amarakośa 2.5.32: pracalāka = barha; the same at Hemacandra's Abhidhānacintāmaṇi 4.386 and Halāyudha's Abhidhānaratnamālā 2.87. 
is also known to the Aṣtāngasamgraha (U. 43.8f.) as a saumya kīta that excites kapha. It seems probable that the Arthaśāstra employs the word in this sense.

So far, there is no trace of a pīlu. However, two passages from the next chapter of the Arthaśāstra refer to the tree in a remarkable context.

(7) AŚ 14.2.22:

pīlutvañmașimayah piṇdo haste jvalati.

ŚM (III/224):

piṇ̦o bolākhyam bheșajam.

J.J. Meyer (1926: 647):

Ein Ball aus dem Ruß der Rinde des pīlu (Careya arborea oder Salvadora persica) gemacht, flammt in der Hand.

Kangle (1972: 501):

A lump, consisting of the soot of the bark of $p \bar{\imath} l u$, burns in the hand.

Shamasastry (1960: 448):

The ball prepared from the powder of the charcoal of the bark of pīlu (careya arborea) can be held in hand and burns with fire.

Sensarma (1998: 91f.):

A lump, prepared from the powder of charcoal of the bark of pillu (Careya arborea Roxb.), emits fire even without ignition, and the same can be held in hand without being injured.

Gaṇapati Śāstrī's Śrīmūlā has no remark on pīlu.

The interpretation of AŚ 14.2.22 is not easy at all. The term mași means soot, lampblack and a substance of the same kind employed as ink. The Śrimūla leads astray, as clearly a ball (pinda) made of the mași of pīlu bark is intended. Its interpretation of the word as a medicine called bola cannot be correct. This medicine called bola is myrrh, the gum-resin derived from Commiphora myrrha (Nees) Engl. = Balsamodendron myrrha Nees, ${ }^{172}$ an inhabitant of the Somali and Arabian littorals of the Red Sea. The earliest medical text mentioning bola is the Aștāngasamgraha. ${ }^{173}$ Meyer's rendering of haste jvalati as 'it flames in the hand' does in

172 See Martinetz et al. 1988.

173 A.s. Ci. 5.87 (5.85-92 is the recipe of a rasāyana ascribed to Vasistha which mentions bolasthavira, interpreted as bolavrkṣa by Indu, as an ingredient) and 7.41 (bolasthavira again an ingredient in a recipe). 
my opinion not convey what is meant; the emission of flames is not intended, but a feeling of burning in the hand as if it is being singed by flames. The author of the Śrim ūla, however, thinks otherwise. He remarks (III/224 ad 14.2.19-21): agninā gātraprajvālanam eteṣv ekaikam gātre 'nuliptam gātrasya pīdām vinaivāgniprajvalanasādhanam ity arthah . The nature of the pilu tree is crucial in this case. The view, enunciated by Meyer and Shamasastry, that a ball made with the soot of the bark or the charcoal of Careya arborea is intended does not appeal, as Careya arborea is not a suitable tree for producing charcoal; this also applies to Salvadora. The wood of Strychnos nux-vomica, on the other hand, is hard and durable, and therefore more appropriate. This small detail may be a second indication that the pīlu of the Arthaśāstra can denote Strychnos nux-vomica Linn.

AŚ 14.2.22 is preceded and followed by a series of similar statements concerning substances which make the body feel as if burning with fire. The next statement (AŚ 14.2.23) says that the ball described, smeared with the muscle fat $(v a s \bar{a})$ of a frog, ${ }^{174}$ gives the same or a stronger effect. ${ }^{175}$ The fat of a frog (mand $\left.\bar{u} k a\right)$ appears to be an essential ingredient in a series of prescriptions of the same kind. ${ }^{176}$

A similar prescription is found at AŚ 14.2.20: pāribhadrakatvañmași mandūkavasaȳa yuktā gātraprajvālanam agninā.

J.J. Meyer (1926: 647):

Ruß von der Rinde der Erythrina fulgens, gemischt mit Froschfett, gibt ein Mittel, die Glieder von Feuer flammen zu machen.

Kangle (1972: 500):

The soot of the bark of paribhadraka, mixed with the fat of a frog, is a means of making limbs burn with fire.

Shamasastry (1960: 447f.):

When the body of a man is rubbed over with the powder of the charcoal of the bark of pāribhadraka (erythrina indica) mixed with the serum of the flesh of mandūka (a frog), it can be burnt with fire (without giving hurt).

174 Does a frog possess muscle fat? Sensarma (1998: 92) assumes vasā to be the serum of the flesh of the animal; he appears to have borrowed this interpretation from Shamasastry.

175 There may be a difference of degree between jvalati and agninā jvalati.

176 It is not without importance to realize that poisonous frogs, well known from South America, do not occur in India. 
Sensarma (1998: 92)

If the body of a person is rubbed over with the powder of charcoal of pāribhadraka (Erythrina variegata Linn. var. orientalis [L.] Merrill) or nimba (Azadirachta indica Juss.), mixed with the serum of the flesh of manduka (Rana tigrina or Bufo melanostictus), the body can glow without harming the person.

The Śśn̄mūlà regards pāribhadraka as a synonym of nimba (Azadirachta indica A.Juss.). ${ }^{177}$ The tree called pāribhadraka is commonly identified as an Erythrina species (Erythrina variegata Linn. = Erythrina indica Lam. or Erythrina stricta Roxb.). ${ }^{178}$ This identity may help in understanding the choice made in the recipe. Erythrina variegata and E. stricta have both eye-catching flowers of a coral-red colour, which may explain the association with fire. This does unfortunately not apply to pilu: Salvadora has inconspicuous flowers, while Careya arborea possesses showy flowers, but of a white, yellowish white or pink colour.

(8) AŚ 14.2.34:

pīlumayo maṇir agnigarbhah suvarcalāmūlagranthih sūtragranthir vā picupariveștito mukhād agnidhūmotsargah.

ŚM (III/226):

pīlumayo maṇih pīludārunirmitam aliñjaram, agnigarbho 'ntargatāgnih, suvarcalāmūlagranthih kṣumāmūlagranthih, sūtragranthir vā kṣumāmūlagranthir vā, picupariveștito nirasthitūlaveștitah.

J.J. Meyer (1926: 648):

Ein aus pīlu gemachtes Kügelchen, das Feuer im Innern birgt, in die Wurzeln der suvarcalā geknotet oder in Leinfäden geknotet und mit Baumwolle umwickelt ist, bildet ein Mittel, aus dem Munde Feuer und Rauch ausgehen zu lassen.

Kangle (1972: 501):

A ball made of $p \bar{\imath} l u$, with fire in the interior, with a knot of the root of suvarcala or with a knot of thread, encircled by cotton, is (a means of) emitting fire and smoke from the mouth.

Shamasastry (1960: 449):

By keeping in the mouth a ball-like piece of pīlu (careya arborea) or a knot of the root of linseed tree (suvarchala) with fire inserted within the

177 Both $P W$ and $M W$ mention that päribhadraka may be a synonym of nimba.

178 Meyer referring to $P W$ and $M W$, has Erythrina fulgens, though both dictionaries give Eryhrina indica as the identity of päribhadra. Erythrina fulgens is probably an old name for E. variegata. 
mass of the ball and wound round with threads and cotton (pichu), volumes of smoke and fire can be breathed out.

Sensarma (1998: 93)

By keeping in the mouth a lump of the wood of pillu (Careya arborea Roxb.) or a knot of the root of suvarcala (Cassia fistula L.) with fire inserted within, and the same is entwined with threads of cotton, volumes of fire and smoke can be breathed out.

Gairola (1962: 917) does not differ from Kangle in his interpretation.

J.J. Meyer remarks in two footnotes (1926: 648, n. 2f.):

Das wird wohl heißen sollen, daß das im Mund zu haltende Kügelchen aus dem Ruß der verbrannten Rinde von Careya arborea (Salvadora Persica?) gemacht ist; denn pilumayo manith ist sehr ähnlich dem $p \bar{\imath}$ lutvañmashīmayah pindah von 414, 7. - [suvarcalā ist] gewöhnlich Ruta graveolens; wächst nach Mahābhārata XII, 272, 4 im Wald und schmeckt bitter. ${ }^{179}$ Nach den Lex. bedeutet das Wort auch eine Hanfpflanze.

Meyer adds (1926: 887):

Auch in Vish. 79,17 wird suvarcala unter anderen scharfen Sachen aufgeführt und beim Totenseelenmahl verboten. Der Absud dieser Pflanze, die auch brāhmi, die heilige, heißt, dient auch als Sündenabführmittel (Vas. XXVII,11; Vish. XLVI,23). ${ }^{180}$

Kangle says in a footnote (1972: 501, note on AŚ 14.2.34):

pīlumayo manih, i.e., a ball made of pīlu wood, which is hollow inside. It cannot be the lump of the soot of its bark, mentioned in s. 2.22, as Meyer thinks. - granthi refers to the stopper at the mouth of the ball; this granthi encircled by cotton (picu) burns and produces the fire and smoke coming out of the mouth.

Gaṇapati Śāstrī remarks that a small water-jar (aliñjara) made of pīlu wood is meant. However, an aliñjara is usually an earthen jar, better suited to the purpose of a water-container than a vessel made of wood.

The interpretations of AŚ 14.2.34 raise more problems than they solve. First, it has to be elucidated whether the mani is the same as the pinda

179 See MBh (B) 12.272.3-4 ( $\approx$ MBh 12.264.3-4): rāsțtre dharmottare śreșthe vidarbheṣv abhavad dvijah / uñchavrttir ṛsih kaścid yajñam yaṣtum samādadhe // śyāmākam aśanam tatra sūryaparṇ̄ suvarcalā / tiktam ca virasam śākam tapasā svādutām gatam //.

180 VS 46.23 and Vāsișthadharmasūtra 27.11 mention brahmasuvarcalā, which differs from suvarcalā. On brahmasuvarcalā, of unknown identity, see Singh - Chunekar 1972: 279-281. Olivelle (1999: 348) remarks that brahmasuvarcala refers either to a variety of sunflower (Helianthus) or to Clerodendrum indicum (Linn.) Kuntze $=$ Clerodendron siphonanthus R.Br. 
mentioned earlier. Opinions differ on this point. Ganapati's suggestion that it is an amulet of $p \bar{\imath} l u$ wood in the form of a water-jar with a stopper in its mouth and fire in its interior seems fanciful. It hinges on the meaning of mukha, considered to be the mouth of the jar. The meaning of mukha, however, is problematic. Meyer and Kangle see in it the mouth of the person holding the ball (mani). Reaching a decision is difficult and depends on the existence of amulets in the India of the Arthaśāstra which have an opening to put something inside, a sacred text written on palm leaf or some other substance, for example. This again presupposes that AŚ 14.2.34 speaks indeed of a hollow object. Though all the translators assume this to be so, it is not imperative at all to interpret agnigarbha mani as a hollow object with actual fire in it. The term agnigarbha may simply refer to the notion that pīlu wood, as in AŚ 14.2.22, possesses a fiery essence. Literally, agnigarbha means "pregnant with fire". Particular gems, such as the sūryakānta, supposed to emit solar heat, are called thus. ${ }^{181}$ In my opinion it is probable that the object described is employed for performing tricks since it occurs among a series of similar recipes, such as that which makes it possible to walk unscathed on burning charcoal, etc., which usually form part of kautūhala-works and those on indrajāla and satkarman.

The description is vague as to the threads to be employed and in particular the granthi. ${ }^{182}$ Has the cotton $($ picu) to be wrapped around the mani or around the granthi? What is the meaning of granthi here and where is it located? I do not see a solution that cannot be objected to. Tying a thread around a spherical object and fixing a knot (sütragranthi) is not an easy task. Even more inconceivable is a granthi made with the root of suvarcalā. In this case, suvarcala should be a plant with threadlike roots.

A much better sense is obtained if we read as follows: ... agnigarbhah, suvarcalāmūlagranthih $<v \bar{a}>$ sūtragranthir vā, picu- ... "... pregnant with fire or a knotty root of suvarcala or a knot of its threads (fibers?) [wrapped] with cotton ...".

The identity of suvarcala is much disputed, and actually no satisfactory identification has been proposed. $P W:$ Ruta graveolens $=\bar{a}$ dityabhakt $\bar{a}$, Flachs $=$ sūryamukhipuspa . The meanings found in $M W$ are Ruta gra-

181 See RN 14.57: atha bhavati — sūryakāntas tapanamaṇis tapanajaś ca ravikāntah / dīptopalo 'gnigarbho jvalanāśmā 'rkopalaś ca vasunāmā //. The same word is a synonym of agnijāra at DhN 6.21ab: agnijāro 'gniniryāsah so 'gnigarbho 'gnijah smrtah /. Finally, the plant called tejasvini has agnigarbhā as one of its names according to $\mathrm{RN} 3.392$.

182 A granthi denotes the knot made in the end of a string. 
veolens, Linum usitatissimum (linseed), and Polanisia icosandra (hemp). Mayrhofer (1956-1980: III/489 and 1986-2001: III/518) adopts Ruta graveolens. Sensarma's opinion that suvarcalā denotes Cassia fistula Linn. (cf. above p. 56) appears to be an idiosyncratic view.

Whichever plant species suvarcala may be, it is not Ruta graveolens Linn., nor Ruta chalepensis Linn., which are both species native to the Mediterranean region and cultivated only in Indian gardens. Polanisia icosandra Wight et Arn. is a no longer valid name for Cleome viscosa Linn., a plant considered as a candidate for the identification of suvarcala in Kirtikar - Basu (1935: I/185). Balwant Singh and Chunekar (1972: 440f.) are of the opinion that two kinds of suvarcala have to be distinguished since the Suśrutasaṃhitā classifies it in two different categories of potherbs with different properties. They think that the potherb tilaparnika of the Carakasamhita ${ }^{183}$ is the same as the second type of Suśruta and identify it as probably Gynandropsis gynandra Briquet = Gynandropsis pentaphylla Linn. To complicate matters further, $\bar{A} y u r v e d i c$ texts are also acquainted with a divine herb called brahmasuvarcalā.

\section{Further References to PīLU}

A special kind of pīlu, mentioned in some lexica, has still to be discussed. This is the pillu growing in mountainous regions and therefore called giripīlu.

This tree is mentioned in the following works:

Bhāgavatapurāṇa 5.14.12:

sa yadā dugdhapūrvasukrtas tad̄̄ kāraskarakākatundādyapunyadrumalatāvișodapānavad ubhayārthaśūnyadravināã jūvanmṛtān svayam jīvan mriyamāna upadhāvati.

Amarakoșa, vanausadhivarga 28:

pīlau gudaphalah sramsī tasmims tu girisambhave / akșotakandarālau dvau ... /I

NŚ 139d-140ab:

(pīlau) ... tasmims tu girisambhave //

aksoṭah karparālaś ca phalasneho guhāśrayah /

${ }^{183}$ Ca. Sū. 27.97 (tilaparṇikā), Cakrapāṇi: = hulahulikā; Ca. Ci. 3.267 (tilaparñ̄e), Cakrapāṇi: hulhul iti khyātā. 
Kṣirasvāmin adds to the verse in the Amarakoṣa:

kandarāsyāstīti kandarāvesțanāt kandarālah, karparāla ity eke. āha ca akșotah parvatīyaś ca phalasneho guhāśayah /

kìresțah kandarālaś ca svādumajjo mrducchadah //

DhN 5.60:

$\bar{a} k s ̣$ dạ pārvatīyaś ca phalasneho gud̄áśrayah /

kīreștah karparālaś ca svādumajjā prthucchadah //

Similarly RN 11.82:

akṣotah pārvatīyaś ca phalasneho gudāśayah

kìreștah kandarālaś ca madhumajjā ḅ̣hacchadah ||

The aksot $a^{184}$ is a tree frequently occurring in the classical medical treatises. ${ }^{185}$ It is commonly identified as the walnut tree, Juglans regia Linn. ${ }^{186}$ The remarkable fact that Kern rendered the pīlu of the Brhatsamhitā as walnut (cf. above p. 36f.) may be due to a confusion of this tree with the giripīlu.

\section{Concluding Remarks and Results}

The rarity of references to Strychnos nux-vomica Linn. in early Indian literature has not been explained so far. The fact that the tree is not rare at all in India, while the very toxic nature of the seeds cannot have passed unnoticed, raises many questions. The same applies even more strongly to Antiaris toxicaria (Pers.) Lesch., source of a famous arrowpoison of Southeast Asia, but mentioned only a few times in Sanskrit literature. ${ }^{187}$ More examples of this intriguing phenomenon can be ad-

184 Variants are: akșoda, ākșota, āksộda.

185 Cakrapānidatta rightly observes that its fruits are found in the North (ad Ca. Sū. 13.10); Dalhạ̣a also remarks that its fruit is well known in the North (ad Su. Sū. 45.120). Arunadatta mentions snehaphala as a synonym (ad A.h. [1939] Sū. 6.120). Hemādri (ad A.h. [1939] Sū. 6.120) describes its fruit as resembling that of madana and with an elevated line in the middle (madhye kimcid unnatarekha).

${ }^{186} P W$ : "Name einer Pflanze (parvatajapiluvrkșa), Croton moluccanum, Aleurites triloba"; $M W$ : "a walnut (pistachio nut?), the tree pilu, the tree Aleurites triloba"; Mayrhofer (1956-1980: I/16 and 1986-2001: III/3): "walnut". Croton moluccanus Willd. is an old name for Chrozophora plicata A.Juss., a species now subdivided into C. prostrata Dalz. (= C. plicata 3 of Hooker 1875-1897) and C. parvifolia Klotzsch (= C. plicata 2 of Hooker 1875-1897). Aleurites moluccana (Linn.) Willd. = Aleurites triloba J.R. et G.Forst. is an evergreen tree, native to the Indo-Malaysian region; the kernels of the nuts yield an oil, known as Lumbang oil, candlenut oil or Indian walnut oil. This tree is naturalized in India, but found in a wild state in South India and Assam.

187 Wealth of India ${ }^{2}(\mathrm{I} / 309)$ records valkala as the Sanskrit name. 
duced. One of these is Peganum harmala Linn., a plant regarded as the source of the Vedic soma by some authorities. Another example is Strychnos colubrina Linn., a lofty, woody climber of the Deccan peninsula; its roots, bark, wood and seeds contain, as do the same parts of Strychnos nux-vomica Linn., the alkaloids strychnine and brucine. ${ }^{188}$

These plants may be present in the lists of dangerous vegetable (and mineral) poisons (sthāvaravisa) in the classical medical works. Surprises may result from a close inspection of this material that has so far been neglected.

Strychnos nux-vomica Linn. (kākapīlu, kupīlu) is mentioned in early Sanskrit literature, though commonly regarded as being absent there and only appearing much later. Two passages from the Kauṭiliya Arthaśāstra (13.1.16 and 14.2.22) may provide evidence that also the tree called pillu can designate Strychnos nux-vomica. The pīlu of the Paippalādasaṃitā (7.19) remains a problem and cannot be regarded as the same tree with certainty. Antiaris toxicaria (Pers.) Lesch., the upas tree, may also be referred to in Sanskrit literature, but rarely.

\section{ReFerences}

Abdul Kareem 1997 M. Abdul Kareem, Plants in Ayurveda (A Compendium of Botanical and Sanskrit Names). Bangalore: Foundation for the Revitalisation of Local Health Traditions, 1997.

Abhidhānacintāmaṇi Abhidhāna Chintāmaṇi of Śr rū Hemachandrāchārya. Edited with an Introduction by Dr. Nemichandra Śāstrī and the Maṇiprabhā Hindī Commentary and Notes by Śrī Haragovinda Śāstrī. [The Vidyabhawan Sanskrit Series 109]. Varanasi: The Chowkhamba Sanskrit Series Office, 1964.

Abhidhānamañjarī Bhișagāryaviracitā abhidhānamañjarī. așțavaidyakulaprabhavena vayaskarāgāranivāsinā nārāyaṇaśarmātmajena śankaraśarmaṇā, ceppāt ka. acyutavaryeṇa ca saṃśodhitā. koțtayanagaryāṃ vaidyasārathimudraṇālayādhipatinā svakīye mudraṇālaye mudrayitvā prakāśitā. [Vaidyasārathigranthāvali 2]. ${ }^{2} 1952$.

Abhidhānaratnamālā Halayudha's Abhidhanaratnamala. A Sanskrit Vocabulary. Edited with a Sanskrit-English Glossary by Th. Aufrecht. Delhi: Indian India, 1975 (repr.).

Abhinayadarpana Nandikeśvara's Abhinayadarpanam-A Manual of Gesture and Posture Used in Hindu Dance and Drama. English Translation, Notes and the Text Critically Edited for the First Time from

188 This species may be the latā vișaphalā of Aśvaghoșa's Buddhacarita (12.6) and the saviṣa latā of the same author's Saundarananda (8.31). 
Agharkar 1953

A.h. (1939)

A.h. (1950)

A.h. (1956-1957)

Ali - Ripley 1983

Amarakośa

Anekārthasamgraha

Āpastambadharmasūtra

A.s.

AŚ

Aștāingahṛdayakoṣa the Original Manuscript by Manmohan Ghosh. Calcutta: Manisha Granthalaya, 1957.

S.P. Agharkar, Gazetteer of Bombay State (Revised Series). General-A, Botany - Part I-Medicinal Plants. Bombay: Government Central Press, 1953.

The Asțangahrdaya, a Compendium of the Ayurvedic System Composed by Vāgbhata, With the Commentaries (Sarvāngasundarā) of Arunadatta and (Āyurvedarasāyana) of Hemādri. Collated by the Late Dr. Aṇnā Moreśwar Kuṇte and Kṛiṣna Rāmchandra Śāstrī Navre. Sixth Edition. Edited by Pt. Bhiṣagāchārya Hariśāstrī Parādkar Vaidya. Bombay: Nirṇaya-sāgar Press, 1939.

Aștāingahrdaya of Vāhața with the Commentary Hṛdayabodhikā of Śrīdāsapandita. Part II (Sūtrasthāna Ch. XVI to XXX). Edited by Dr. P.K. Narayana Pillai. [Trivandrum Sanskrit Series 155]. Trivandrum: University of Trivandrum, 1950.

Aștāingahṛdaya (sūtrasthāna). śrī aruṇadatta kṛt sarvāngasundarā śrī candranandana kṛt padārthacandrikā va śrī hemādri kṛt āyurveda rasāyana țīkā, rājyavaidya paṃ. rāmprasādjī śarmā kṛt țippaṇ̄ sahit. Bombay: Śrīveńkațeśvar Steam Press, 1956-1957.

Salim Ali - S. Dillon Ripley, Handbook of the Birds of India and Pakistan, Together with Those of Bangladesh, Nepal, Bhutan and Sri Lanka. Delhi etc.: Oxford University Press, 1983.

The Nāmalingānuśāsana Amarakośa of Amarasimnha with the Commentary (Amarakośodghătana) of Kșirasvāmin. Edited with Critical Notes, an Essay on the Time of Amarasimpha and Kṣinasvāmin, a List of Works and Authors Quoted, Glossary of Words, etc. etc. by Krishnaji Govind Oka. Delhi - Varanasi: Upāsanā Prakāshan, 1981.

Śrīhemacandrācāryaviracitah anekārthasamgraho nāma kośah. sampādakāḥ jagannāthaśāstrī hośinga, ghanānandapāṇḍeyạ kūrmācalīyaḥ, janārdanajyotirvit tārādattah. [Kāśs Saṃskṛt Granthamāā 68 ]. Vārānasīi: Caukhambā Saṃskṛt Sīrij Āphis, 1969.

The Āpastambadharmasūtra with the 'Ujjvala' Commentary of Śr ru Haradatta Miśra and Notes by Śri A. Chinnaswāmi Śāstrī and Pandit A. Rāmanātha Śāstrī. Edited with Hindi Translation, Explanatory Notes, Critical Introduction and Index by Dr. Umeśa Chandra Pāṇdeya. [The Kashi Sanskrit Series 93]. Varanasi: The Chowkhamba Sanskrit Series Office, 1969.

Śr̄madvṛddhavāgbhataviracitah aștāingasangrahah induvyākhyāsahitah. sampādakaḥ vaidya anant dāmodar āthavale. Pune: Maheś Anant Āthavale, 1980.

Arthaśāstra, see Kangle 1969.

The Ashtanga Hridaya Kosha with the Hridaya Prakasha (A Critical and Explanatory Commentary). Trichur: Mangalodayam Press, 1936. 
Aśvaśāstra

Atharvaveda

Aufrecht 1873

Āyurvedasaukhya

Āyurvedīya śabdakośa

Áyurvedīya viśvakośa

Bāpālāl Vaidya 1982

Bāpālāl Vaidya 1985
Aśvaśāstram by Nakula with Coloured Illustrations. Edited by S. Gopalan, Assisted by V. Svāminātha Ātreya and K.S. Subramanya Śāstri. [Tanjore Saraswati Mahal Series 56]. Tanjore: T.M.S.S.M. Library, 1952.

Atharvaveda, Śaunakīya recension, see Whitney 1905

Th. Aufrecht, Ueber die Paddhati von Çârnigadhara. Zeitschrift der Deutschen Morgenländischen Gesellschaft 27 (1873) 1-120.

Diagnosis and Treatment of Diseases in Ayurveda Based on Ayurveda Saukhyam of Todarānanda. Part Four, by Vaidya Bhagwan Dash and Vaidya Lalitesh Kashyap. [T Todarānanda - Ayurveda Saukhyam Series 6]. New Delhi: Concept Publishing Company, 1987.

see Jośī - Jośī 1968

see Siṃha - Siṃha 1969

Bāpālāl Vaidya, Some Controversial Drugs in Indian Medicine. [Jaikrishnadas Ayurveda Series 33]. Varanasi - Delhi: Chaukhambha Orientalia, 1982.

Id., Nighantu ädarśa (uttarārdha). [The V. Ayurveda Series 54]. Varanasi: Chaukhambha Bharati Academy, 1985.

Baudhāyanadharmasūtra see Olivelle 1999

Bhāgavatapurāṇa

Maharșivedavyāsaprañ̄tam śrīmadbhāgavatapurānam (sacitram

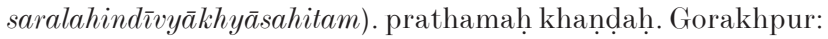
Gītāpres, 1952-1953.

Bhaiṣajyaratnāvalī Śñ̄govindadāsaviracitā bhiṣagratnaśrībrahmaśankaramišreṇa pa-

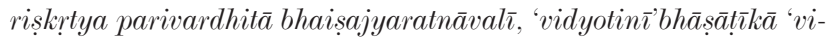
marśa'tippaṇisahitā. ț̣̄kākārah kavirāja śrī ambikādattaśāstrī āyurvedācārya, sampādakah śrī rājeśvaradattaśāstrī āyurvedaśāstrācārya. [Kāśì Saṃskṛt Granthamālā 152]. Banāras: Caukhambā Saṃskṛt Pustakālaya, 1951.

Bhat 1981

M. Ramakrishna Bhat, Varāhamihira's Bṛhat Samhitā. With English Translation, Exhaustive Notes and Literary Comments. Part I. Delhi: Motilal Banarsidass, 1981.

BhPN

Bhāvaprakāśa Nighantutu (Indian Materia Medica) of Śs̄ Bhāvamiśra (c. 1500-1600 A.D.). Commentary by Dr. K.C. Chunekar. Edited by Dr. G.S. Pandey. [The Vidyabhawan Ayurveda Granthamala 28]. Varanasi: Chaukhambha Sanskrit Sansthan, ${ }^{5} 1977$.

Bodding 1925-1940 O.P. Bodding, Studies in Santal Medicine and Connected Folklore. Parts I-III. Calcutta: The Asiatic Society, 1925-1940 (repr. 1986).

Bollée 1995

Willem B. Bollée, The Nijjuttis on the Seniors of the Śvetâmbara Siddhânta: Āyāranga, Dasaveyāliya, Uttarajjhāyāand Sūyagada. [Beiträge zur Südasienforschung 169]. Stuttgart: Franz Steiner, 1995.

Bollée 2005

Id., The Story of Paesi (Paesi-Kahānayam) or Soul and Body in 
Ancient India. A Dialogue on Materialism in Ancient India (Text, Translation, Notes and Glossary). [Pandit Nathuram Premi Research Series 2]. Mumbai: Hindi Granth Karyalay, 2005.

Brahmāndapurāna

Brahmapurāṇa

BS

Buddhacarita

Bühler 1886

Ca.

Ca. (1890-1925)

Ca. (1927-1933)

Ca. (1941)
Brahmānda Purāna of Sage Krșna Dvaipāyana Vyāsa (With Introduction in Sanskrit and English and an Analytical Index of Verses). Edited by Prof. J.L. Shastri. Delhi etc.: Motilal Banarsidass, 1973.

Brahmapurāna. Summary of Contents, With Index of Names and Motifs by Renate Söhnen and Peter Schreiner. [Purāna Research Publications Tübingen 2]. Wiesbaden: Otto Harrassowitz, 1989.

Bṛhatsaṃhitā śrūvarāhamihirācāryaviracitā bhattotpalavivrtisahitā. prathamo bhāgah, dvitīyo bhāgah. sampādakah avadhavihārī tripāthī. [Sarasvat̄̄bhavanagranthamālā 97]. Vārāṇasī: jyotiṣavibhāgādhyakṣah vārāṇaseyasaṃskṛtaviśvavidyālayaḥ, 1968.

Aśvaghosa's Buddhacarita or Acts of the Buddha. Complete Sanskrit Text with English Translation. Cantos I to XIV Translated from the Original Sanskrit Supplemented by the Tibetan Version Together with an Introduction and Notes by E.H. Johnston. 2 vols. Calcutta: Baptist Mission Press, published for the University of the Panjab, Lahore, 1935-1936 (repr. Delhi: Motilal Banarsidass, 1978).

Georg Bühler, The Laws of Manu. Translated With Extracts from Seven Commentaries. [The Sacred Books of the East 25]. Oxford: Clarendon Press, 1886.

The Charakasamhitā by Agniveśa Revised by Charaka and Dṛidhabala, With the Āyurveda-Dīpikā Commentary of Chakrapānidatta. Edited by Vaidya Jādavji Trikamji Āchārya. Bombay: Nirṇaya Sāgar Press, ${ }^{3} 1941$.

Charaka-Samhita (Translated into English) by the Late Kaviraj Avinash Chandra Kaviratna. Published by his Son Kaviraj Pareshnath Sarma Kavibhusan. Calcutta: Kaviratna Press, 1890-1925. Second Revised Edition: Caraka Samhitā. Translated by A. Chandra Kaviratna and P. Sharma. Preface by Jan Erik Sigdell. 5 vols. [Indian Medical Science Series 41]. Delhi: Sri Satguru Publications, 1996-1997.

Caraka-saṃhitā mahāmuninā bhagavatāgniveśena prañ̄tā maharșicarakena pratisamskṛtā. carakacaturānana-śrīmaccakrapāṇidattapraṇītayā āyurvedadīpikākhyațīkayā mahāmahopādhyāya-śrīgaṅgādharakaviratnakavirājaviracitayā jalpakalpatarusamākhyayā țīkayā ca samalan̉kṛtā. kavirājaśrīnarendranāthasenaguptena kavirājaśrībalāicandrasenaguptena ca sampāditā samśodhitā prakāśitā ca. 3 vols. Calcutta: Dhanvantariṣtīmmeśinyantra, 1927, 1928, 1933.

Carakasaṃhitā, mahāmahopādhyāyacarakacaturānanaśrīcakra-

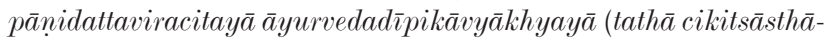


Ca. (1949)

Ca. (1954-1962)

Ca. $(1962)$

Ca. (1983a)

Ca. $(1983 b)$

Ca. (1989)

Ca. (1997)

Cārucaryā natah siddhisthānam yāvat) śrīvāgbhațasisyācāryavarajajjațaviracitayā nirantarapadavyākhyayā ca samvvalitā. āyurvedācāryeṇa paṃ. śrīharidattaśāstrinā saṃśodhitā pūritajajjațațīkātruṭitāṃ́abhāgā ca. dvitīyo bhāgah. Bombay: Śrīmotīlāl Banārsīdās, 1941.

The Caraka Samhitā. Expounded by the Worshipful Ātreya Punarvasu, Compiled by the Great Sage Agniveśa and Redacted by Caraka and Dridhabala. Edited and Published in Six Volumes with Translations in Hindi, Gujarati and English by Shree Gulabkunverba Ayurvedic Society. Vol. IV. Jamnagar: Shree Gulabkunverba Ayurvedic Society, 1949.

Caraka-saṃhitā maharṣi agniveś prañ̄t (saral bhāṣānuvād sahit). anuvādak: Śrī Vinaycandra Vāsiștha, Śrī Paṇdit Jaydev Śarmā pariṣkrt. 3 vols. Ajmer: Ārya Sāhitya Maṇdal, 1954, 1957, 1962.

The Charaka Samhita of Agniveśa Revised by Charaka and Dṛdhabala. With Introduction by Vaidya-Samrāta Shri Satya Narayana Shastri Padmabhushana with Elaborated Vidyotini Hindi Commentary by Pt. Kashi Nath Pandeya and Dr. Gorakh Nath Chaturvedi. 2 vols. Varanasi: Chowkhamba Vidya Bhawan, 1962.

Caraka-samhitā. Agniveśa's Treatise Refined and Annotated by Caraka and Redacted by Drdhabala (Text with English Translation). Editor - Translator Prof. Priyavrat Sharma. Vol. II (Cikitsāsthānam to Siddhisthānam). [Jaikrishnadas Ayurveda Series 36]. Varanasi - Delhi: Chaukhambha Orientalia, 1983.

The Caraka-samhitā (as Precepted by the Great Sage Ātreya Punarvasu) of Agniveśa, Elaborated by Caraka and Drdhabala. Edited with 'Charaka-Chandrika' Hindi Commentary along with Special Deliberation etc. by Dr. Brahmanand Tripathi. 2 vols. [The Chaukhamba Ayurvijnan Granthamala 11]. Varanasi: Chaukhamba Surbharati Prakashan, 1983.

Śrīmanmaharșipravaracarakapran̄itā carakasaṃhitā. āyurvedoddhārakavaidyapañcānanavaidyaratnarājavaidyapaṇditarāmaprasādavaidyopadhyāyaviracitā evạ̣ āyurvedācārya pạ̣ śivaśarmaṇa saṃśodhitā prasādanī bhāṣāṭīkāsahitā. prathamo bhāgah, dvitīyo bhāgah. Bambaī: Khemrāj Śrīkṛ̣ṇadās Bambaī Prakāśan, 1989.

Agniveśa's Caraka Saṃitāa. Text with English Translation and Critical Exposition Based on Cakrapāṇi Datta's Āyurveda Dīpikā by Dr. Ram Karan Sharma and Vaidya Bhagwan Dash. Volume IV (Cikitsa Sthana Chap. XV-XXVI). [Chowkhamba Sanskrit Studies 94]. Varanasi: Chowkhamba Sanskrit Series Office, 1997.

Cārucaryā by Bhoja Raja (A Medieval Work on Personal Hygiene). Edited by B. Rama Rao. Hyderabad: Indian Institute of History of Medicine, 1974. 
Chattopadhyay 1967

Chattopadhyay 1993a

Chattopadhyay $1993 \mathrm{~b}$

Chopra et al. 1940

Chopra et al. 1956

Ci.

Cikitsāsaṃgraha (1933)

Cowell - Thomas 1897

Dange 1986

Dastur 1962

Dave 1985

Deśīnāmamālā

DhN
Aparna Chattopadhyay, Peacock's Flesh - the Favourite Dish of Emperor Asoka. Indian Medical Gazette $7 / 8$ (1967) (pagination unknown).

Id., Studies in Ancient Indian Medicine. Part I. Varanasi: Aparna Chattopadhyay, 1993.

Id., Ancient Indian Practice of Eating Peacock's Flesh. In: Studies in Ancient Indian Medicine (see Chattopadhyay 1993a), p. 66-74.

Sir Ram Nath Chopra - Rattan Lall Badhwar - Sudhamoy Ghosh, Poisonous Plants of India. Vol. 1. Jaipur: Academic Publishers, 1984 (orig. publ. Calcutta 1940).

R.N. Chopra - S.L. Nayar - I.C. Chopra, Glossary of Indian Medicinal Plants. New Delhi: Council of Scientific and Industrial Research, 1956.

Cikitsāsthāna

Cakradattah cikitsāsamgrahagranthah. mahāmahopādhyāyacarakacaturānanaśrīmaccakrapāṇidattena viracitah, śrīśivadāsasenaviracitayā tattvacandrikāsamākhyayā vyākhyayā samalan̉krtah. panditakulapati vi.e. upādhidhāriśrīmajjīvānandavidyāsāgarabhatțācāryātmajābhyām paṇditaśrīmadāśubodhavidyābhūṣaṇapaṇịtaśrīmannityabodhavidyāratnābhyāṃ pratisaṃskṛtah prakāśitaś ca. Kalikātā: Vācaspatyayantra, 1933.

E.B. Cowell - F.W. Thomas (tr.), The Harsa-carita of Bāna. London: Royal Asiatic Society, 1897 (repr. Delhi: Motilal Banarsidass, 1968).

Sadashiv Ambadas Dange, Encyclopaedia of Puranic Beliefs and Practices. Vol. I $(A-C)$. New Delhi: Navrang, 1986.

J.F. Dastur, Medicinal Plants of India and Pakistan. Bombay: D.B. Taraporevala Sons and Co., 1962.

K.N. Dave, Birds in Sanskrit Literature. Delhi etc.: Motilal Banarsidass, 1985.

The Deśñnamamālā of Hemacandra. Edited with the Help of Two MSS. and Pischel's Edition of 1880 with an Introduction, Index to the Text and Commentary and English Translation of the Text and Extracts from the Commentary of Hemachandra with a Complete Glossary of Deśī Words from All Sources with References, Derivation and Meanings by Muralydhar Banerjee. Part I: Text with Readings, Introduction and Index of Words. Calcutta: University of Calcutta, 1931.

Rājanighantusahito dhanvantarīyanighantuh . etat pustakam ve.śā. rā.rā. "purandare"ity upanāmakair vițthalātmajair vaidyanārāyaṇaśarmabhị̣ saṃśodhitam, tac ca bī.e. ity upapadadhāribhị̣ vināyak ganeś āpṭe ity etaị puṇyākhyapattane ānandāśramamudraṇālaye àyasākṣarair mudrayitvā prakāśitam. [Ānandāśramasamsskṛtagranthāvali 33]. ${ }^{2} 1925$. 
Dubey - Singh 2005

Dutt 1877

Dutt 1922

Dymock et al.

1890-1893

Flückiger - Hanbury 1879

Gadanigraha

Gairola 1962

Gaṇapati Śāstrī 1924-1925

Gautamadharmasūtra
Satya Deo Dubey - Anugrah Narain Singh (ed.), Six Decades of Ayurveda (1941-2000). A Collection of the Selected Articles and Lectures by Prof. Priya Vrat Sharma. [Vrajajiwan Ayurvijnan Granthamala 37]. Delhi: Chaukhamba Sanskrit Pratishthan, 2005.

Udoy Chand Dutt, The Materia Medica of the Hindus. Compiled from Sanskrit Medical Works by Udoy Chand Dutt, Civil Medical Officer, With a Glossary of Indian Plants by George King, Superintendent, Royal Botanical Garden, Calcutta, and the author. Calcutta: Thacker, Spink and Co., 1877.

Id., The Materia Medica of the Hindus. Compiled from Sanskrit Medical Works by Udoy Chand Dutt, Civil Medical Officer, With a Glossary of Indian Plants by George King, Superintendent, Royal Botanical Garden, Calcutta, and the author. Revised Edition, With Additions and Alterations by Kaviraj Binod Lall Sen, Kaviraj Ashutosh Sen and Kaviraj Pulin Krishna Sen (Kavibhushan), Published by Madan Gopal Dass for the Proprietor at the Adi-Ayurveda Machine Press. Calcutta 1922.

William Dymock - C.J.H. Warden - David Hopper, Pharmacographia Indica. A History of the Principal Drugs of Vegetable Origin Met with in British India. 3 vols. London: Kegan Paul, Trench, Trübner and Co. 1890, 1891, 1893 (repr. in Hamdard: The Organ of the Institute of Health and Tibbi Research, Pakistan 15, 1-12 [1972]).

Friedrich A. Flückiger - Daniel Hanbury, Pharmacographia. A History of the Principal Drugs of Vegetable Origin Met with in Great Britain and British India. London: MacMillan, 1879 (repr. Dehra Dun: International Book Distributors, 1986).

Gadanigraha of Śr̄̄ Vaidya Sodhala. With the 'Vidyotin̄̄' Hindī Commentary by Śrī Indradeva Tripāṭī. Edited by Śrī Gañgā Sahāya Pāndeya. Parts I (Prayoga Khanda), II (Kāyacikitsā Khanda), III (from Śalākya to Pañchakarma). [The Kashi Sanskrit Series 182]. Varanasi: The Chowkhamba Sanskrit Series Office, 1968, 1968, 1969.

Śrī Vāchaspati Gairola, The Artha Śāstra of Kautilya and the Cānakya-sūtra. Edited with Introduction, Hindi Translation and Glossary. [The Vidyabhawan Sanskrit Granthamala 75]. Varanasi: The Chowkhamba Vidya Bhawan, 1962.

Śrīmūlā commentary on AŚ. In: T. Gaṇapati Śāstrī (ed.), The Arthaśāstra of Kauțalya. 3 vols. [Trivandrum Sanskrit Series 79, 80, 82]. Trivandrum: Government Press, 1924-1925 (repr. Delhi - Varanasi: Bharatiya Vidya Prakashan, 1984).

The Gautama-dharma-sūtra with the Mitākșarā Sanskrit Commentary of Haridatta. Edited with the Hindi Commentary and Introduction by Umesh Chandra Pandey. [Kashi Sanskrit Series 172]. Varanasi: Chaukhamba Sanskrit Series Office, 1966. 
Griffiths 2009

Guérinot 1902

Gupta 1983

Harșacarita

HIML IB

Hooker 1875-1897

Hopkins 1915

Ingalls 1965

Jacobi 1895

Jīvaviyāra

Johnson 1962

Jolly 1880

Jośī- Jośī 1968
Arlo Griffiths, The Paippalādasamhita of the Atharvaveda, Kāndas 6 and \%. A New Edition with Translation and Commentary. [Groningen Oriental Studies 22]. Groningen: Egbert Forsten, 2009.

A. Guérinot, Le Jīvaviyāra de Śāntisūri - un traité Jaina sur les êtres vivants. Texte prâcrit, traduction française, notes et glossaire par A. Guérinot. Journal Asiatique, Neuvième série, tome 19 (1902) 231-288.

Kavirāja Umeśachandra Gupta, Vaidyaka-śabdasindhuh [Comprehensive Glossary of Āyurvedic Technical Terms with Synonyms of Sanskrit, Latin, Hindi, Tamil, Telugu, Bengali etc. and Having References of Standard Āyurvedic Texts]. Revised and Enlarged Second Edition by Kavirāja Nagendra Nātha Sena. [Jaikrishnadas Ayurveda Series 56]. Varanasi - Delhi: Chaukhambha Orientalia, ${ }^{3} 1983$ (orig. publ. Calcutta 1914).

The Harsacharita of Bānabhatta with the Commentary Sanketa of Śankarakavi. Edited by Kāśināth Pāṇụañg Parab, Reedited by Nārāyạ̣ Rām Āchārya "Kāvyatīrtha". Bombay: Nirṇaya Sāgar Press, ${ }^{7} 1946$.

G. Jan Meulenbeld, A History of Indian Medical Literature. Volume IB: Annotations. [Groningen Oriental Studies 15]. Groningen: Egbert Forsten, 1999.

Sir J.D. Hooker, Flora of British India. 7 vols. London: L. Reeve, 1875-1897 (repr. London: L. Reeve and Co. Ltd., 1961).

E. Washburn Hopkins, Epic Mythology. [Grundriss der IndoArischen Philologie und Altertumskunde, III. Band, 1. Heft B]. Strassburg: Verlag von Karl J. Trübner, 1915 (repr. Delhi etc.: Motilal Banarsidass, 1974).

Daniel H.H. Ingalls (tr.), An Anthology of Sanskrit Court Poetry. Vidyākara's "Subhāṣitaratnakoșa". [Harvard Oriental Series 44]. Cambridge, Mass.: Harvard University Press, 1965.

Hermann Jacobi (tr.), Jaina Sutras, Translated from Prakrit. Part II: The Uttarâdhyayanasîtra, The Sûtrakritângasûtra. [The Sacred Books of the East 45]. Oxford: Clarendon Press, 1895.

see Guérinot 1902

Helen M. Johnson (tr.), Trișaștiśalākāpurusacaritra or The Lives of Sixty-three Illustrious Persons by Ācārya Śr̄ Hemacandra. Vol. VI (Book X). [Gaekwad's Oriental Series 140]. Baroda: Oriental Institute, 1962.

J. Jolly (tr.), The Institutes of Viṣnu. Oxford: Clarendon Press, 1880 (repr. Delhi etc.: Motilal Banarsidass, 1977).

Veṇīmādhavaśāstrī Jośī - Nārāyan Harī Jośī, Āyurved̄̄ya mahākośah arthāt āyurved̄̄ya śabdakośah. saṃskṛt-saṃskṛt. prathamaḥ khaṇdah. Mumbaī: Mahārāṣtra Rājya Sāhitya āṇi Samskṛti Mandal, 1968. 
Ka.

Kaiyadevanighaṇṭu

Kāmaratna

Kamat 2006

Kangle 1965

Kangle 1969

Kangle 1972

Kapadia 1962

Kāśyapasaṃhitā

Kern 1913

Kirtikar - Basu 1935

Maclean 1893
Kalpasthāna

Kaiyadeva-nighantuh (pathyāpathya-vibodhakah). Edited and Translated [into Hindī] by Prof. Priyavrata Sharma and Dr. Guru Prasada Sharma. [Jaikrishnadas Ayurveda Series 30]. Varanasi - Delhi: Chaukhambha Orientalia, 1979.

Yogeśvaraśrīyutagaurīputranityanāthaviracitam kāmaratnam . murādābādanivāsiśrīyutapaṇditajvālāprasādamiśrakṛtahindīțīkāsahitam. Bombay: Lakṣmīveñkaṭeśvar Steam Press, 1962.

S.D. Kamat, Studies on Medicinal Plants and Drugs in Sarasvatīnighantuh. Originally Edited by Late Vd. J.P. Jayatilak in 1918. Further Edited With Notes and Discussions. [The Chaukhamba Ayurvijnan Studies 74]. Delhi: Chaukhamba Sanskrit Pratishthan, 2006.

Id., The Kautilīya Arthaśāstra. Part III: A Study. [University of Bombay Studies. Sanskrit, Prakrit and Pali 3]. Bombay: University of Bombay, 1965.

R.P. Kangle, The Kautilīya Arthaśāstra. Part I: A Critical Edition With a Glossary. [University of Bombay Studies. Sanskrit, Prakrit and Pali 1]. Bombay: University of Bombay, ${ }^{2} 1969$.

Id., The Kautilīya Arthaśāstra. Part II: An English Translation with Critical and Explanatory Notes. [University of Bombay Studies. Sanskrit, Prakrit and Pali 2]. Bombay: University of Bombay, ${ }^{2} 1972$.

Hiralal R. Kapadia, The Jaina Records About Birds. Annals of the Bhandarkar Oriental Institute 43 (1962) 59-107.

The Käśyapa Samhitā (or Vṛddhajivakīya Tantra) by Vṛddha Jivvaka, Revised by Vātsya. With Sanskrit Introduction by Nepal Rajaguru Pandit Hemarāja Śarmā, With the Vidyotinī Hindi Commentary and Hindi Translation of Sanskrit. Introduction by Āyurvedālankār Śrī Satyapāla Bhiṣagāchārya. [The Kashi Sanskrit Series 154]. Banaras: The Chowkhamba Sanskrit Series Office, 1953.

H. Kern, The Bṛhat-Saṃhitā or Complete System of Natural Astrology of Varāhamihira. Translated from Sanskrit into English. In: Verspreide Geschriften, onder zijn toezicht verzameld. Deel I-II: Voor-Indië. 's-Gravenhage: Martinus Nijhoff, 1913, I/169-319 (Chapters I-XLIX) \& II/1-154 (Chapters L-CVI).

Lt.-Colonel K.R. Kirtikar - Major B.D. Basu - An I.C.S., Indian Medicinal Plants. 4 vols. Second Edition, Edited, Revised, Enlarged, and Mostly Rewritten by E. Blatter, J.F. Caius and K.S. Mhaskar. Allahabad: Lalit Mohan Basu, 1935 (repr. Delhi 1981).

C.D. Maclean, Glossary of the Madras Presidency. Containing a Classification of Terminology, a Gazetteer and Economic Dictionary of the Province and Other Information, the Whole 
Madanādinighaṇṭ̣

Madanapālanighaṇṭu

Maheshwari 2003

Mānasollāsa

Manusmṛti

Mārkaṇḍeyapurāṇa

Martinetz et al. 1988

Matsyapurāṇa

Mayrhofer 1956-1980

Mayrhofer 1986-2001

$\mathrm{MBh}$

$\operatorname{MBh}(\mathrm{B})$

MeCann n.d.

Medinīkośa
Arranged Alphabetically and Indexed. Madras 1893 (repr. New Delhi: Asian Education Services, 1982).

Candranandana's Madanādi-nighantu. Edited by Așta Vaidya Vayaskara N.S. Mooss. [Vaidyasarathy Sanskrit Series 8]. Kottayam: Vaidyasarathy Press, 1985.

Nrpamadanapālaviracitah madanapālanighantụh. vaidyaratnāyurvedoddhārakavaidyapañeānanapaṇditarāmaprasādavaidyopādhyāyarājavaidyapațiyālāviracitabhāṣātattvaprakāśinīnāmabhāṣāṭīkāsahitah. Bambaī: Lakṣmīveñkaṭeśvar Steam Press, 1954 .

J.K. Maheshwari, Ethnobotany and Medicinal Plants of Indian Subcontinent. Jodhpur: Scientific Publishers, 2003.

Mānasollāsa of King Someśvara. Edited with an Introduction by G.K. Shrigondekar. Vol. II. [Gaekwad's Oriental Series 84]. Bombay: Bombay Vaibhav Press, 1939.

The Manusmrti. With the Commentary Manvarthamuktāvali of Kullūka, Various Readings, Foot-notes, Indices etc. Tenth Edition, Edited with Critical and Explanatory Notes etc. by Nārāyạ̣ Rām Āchārya "Kāvyatīrtha". Bombay: Nirṇaya Sāgar Press, 1946.

Mārkaṇdeyapurāṇa. Edited by Rāma Śarmā Ācārya. 2 vols. Bareli 1971.

Dieter Martinetz - Karlheinz Lohs - Jörg Janzen, Weihrauch und Myrrhe. Kulturgeschichte und wirtschaftliche Bedeutung - Botanik - Chemie - Medizin. Stuttgart: Wissenschaftliche Verlagsgesellschaft, 1988.

Śr̄̄maddvaipāyanamuniprañ̄tam matsyapurānam. etat pustakam ānandāśramasthapaṇditaih saṃśodhitam. [Ānandāśramasaṃskṛtagranthāvali 54]. Pune: Ānandāśrama Press, 1981.

Manfred Mayrhofer, Kurzgefaßtes etymologisches Wörterbuch des Altindischen / A Concise Etymological Sanskrit Dictionary. 4 vols. Heidelberg: Carl Winter Universitätsverlag, 1956-1980.

Id., Etymologisches Wörterbuch des Altindoarischen. 3 vols. Heidelberg: Universitätsverlag C. Winter, 1986-2001.

The Mahābhārata. Text as Constituted in its Critical Edition. Published by R.N. Dandekar. 4 vols. Poona: Bhandarkar Oriental Research Institute, 1971-1975.

Shriman Mahābhāratam with Bharata Bhawadeepa by Nilkantha. Edited by Pandit Ramchandrashastri Kinjawadekar. 6 vols. Poona: Chitrashala Press, 1929-1933.

Charles McCann, Trees of India. A Popular Handbook, Illustrated with 78 Coloured Plates and 17 Black and White Illustrations. Bombay: D.B. Taraporevala Sons and Co., n.d.

Nānārtha Śabda Kośa or Medin̄ Kośa of Śr $r \bar{\imath}$ Medin̄̄kara. Edited with an Introduction, Index etc., by Sāhityāchārya Pt. Ja- 
Meyer 1926

Misra 1982

Mohanty - Rout 2003

Murray 1881

Murthy 1980

Muthulakshmi 2004

$M W$

Nadkarni 1954

Nāradapurāṇa

Nighaṇțuratnākara

NŚ gannāth Śāstrī Hośing. [The Kashi Sanskrit Series 41]. Varanasi: The Chowkhamba Sanskrit Series Office, ${ }^{3} 1968$.

Johann Jakob Meyer, Das altindische Buch vom Welt- und Staatsleben. Das Arthaçāstra des Kauțilya. Leipzig: Otto Harrassowitz, 1926 (repr. Graz: Akademische Druck- und Verlagsanstalt, 1977).

Shiva Sheikhar Misra, Fine Arts and Technical Sciences in Ancient India with Special Reference to Someśvara's Mānasollāsa. [Krishnadas Sanskrit Studies 3]. Varanasi: Krishnadas Academy, 1982.

R.B. Mohanty - M.K. Rout, Ethnobotany of Careya arborea Roxb. Some Noteworthy Folk Uses in Orissa. In: Maheshwari 2003, p. 505-508.

James A. Murray, The Plants and Drugs of Sind. Being a Systematic Account, with Descriptions, of the Indigenous Flora, and Notices of the Value and Uses of their Products in Commerce, Medicine, and the Arts. London: Richardson and Co., 1881 (repr. Delhi: Indian Book Gallery, 1983).

S.R.N. Murthy, The Vedic River Sarasvatī - a Myth or a Fact. A Geological Approach. Indian Journal of History of Science 15,2 (1980) 189-192.

S. Muthulakshmi, Antiaris toxicaria Lesch (Urticaceae). An Important Medicinal and Poisonous Tree in Courtallam. In: Thas 2004, p. 72 (abstract).

Monier Monier-Williams, A Sanskrit-English Dictionary. Etymologically and Philologically Arranged with Special Reference to Cognate Indo-European Languages. New Edition, Greatly Enlarged and Improved with the Collaboration of Professor E. Leumann, Professor C. Cappeller and Other Scholars. Oxford: Clarendon Press, 1899 (repr. Oxford: University Press Oxford, 1951).

Dr. K.M. Nadkarni's Indian Materia Medica. With Ayurvedic, Unani-Tibbi, Siddha, Allopathic, Homeopathic, Naturopathic and Home Remedies, Appendices and Indexes. Third Edition, Revised and Enlarged by A.K. Nadkarni. Vol. One. Bombay: Popular Book Depot, 1954.

The Nārada-Purāna. Translated and Annotated by Hemendra Nath Chakravorty. Part III. Delhi etc.: Motilal Banarsidass, 1982.

Nighantu Ratnakkar. A Compendium of the System of the Hindū Medicine. Part I: Aușadhigunadoṣa. Paribhāṣā, panchakașāya, rasāyana, śabdakoṣa etc., etc. Edited by Bhiṣagvarya Late Kriṣnaśāstrī R. Navre, Collated with Specious Notes by Vāsudev Laxmaṇ Śāstrī Paṇśikar and Kriṣnājī Vițthal Somaṇ. Bombay: Nirṇaya-sāgar Press, 1936.

Āc. Hemacandrasūri's Nighantusesa with Vācanācārya Śrī Śr̄̄vallabhagani's Commentary. Edited by Munirāja Śrī Punya- 
Olivelle 1999

Pañcatantra

Pandey 2001

Paryāyamuktāvalī

Paryāyaratnamālā

PS

$P W$

Rājatarangiṇī

Rāmāyaṇa

Rișțasamuccaya

RN

Ṣaḍrasanighaṇtu

Śāligrāmanighanțubhüșana

Śārngadharapaddhati vijayaji. [Lalbhai Dalpatbhai Series 18]. Ahmedabad: Lalbhai Dalpatbhai Bharatiya Sanskriti Vidyamandira, 1968.

Patrick Olivelle, Dharmasütras. The Law Codes of Āpastamba, Gautama, Baudhāyana, and Vasiștha. Translated from the Original Sanskrit and Edited. Oxford: Oxford University Press, 1999 .

Viṣnuśarmasaṃkalitam pañcatantram. saralațīkayā viṣaya-padyānukramakośādibhih pro. dāmodara dharmānanda kosambī ity eteṣām prāstāvikena ca sanāthīkṛtam. śrīmad indirākāntatīrthacaraṇāntevāsibhị̣ nārāyaṇa rāma ācārya "kāvyatīrtha" ity etaih svīyavyākhyānādibhih samalaṃkṛtya saṃ́odhitam. Bombay: Nirṇaya Sāgar Press, ${ }^{9} 1950$.

Gyanendra Pandey, Dravyagun Vijñān (Materia Medica - Vegetable Drugs). Part II $(K-N)$. [Krishnadas Ayurveda Series 48]. Varanasi: Krishnadas Academy, 2001.

Paryāyamuktāval̄ of Haricharanasena. Edited by Tarapada Chowdhury. Reprinted from Journal of the Bihar Research Society 31-32. Patna 1947.

Paryāyaratnamālā by Mādhavakara. Edited by Tarapada Chowdhury. Reprinted from Patna University Journal 2. Patna 1946 .

Paippalādasaṃhitā, see Griffiths 2009

Sanskrit-Wörterbuch. Hrsg. von der Kaiserlichen Akademie der Wissenschaften, bearbeitet von Otto Böhtlingk und Rudolf Roth. Theil I-VII. St. Petersburg: Kaiserliche Akademie der Wissenschaften, 1855(1852)-1875 (repr. Wiesbaden: Otto Harrassowitz, 1966).

see Stein 1900

The Rāmāyana of Vālmīki with the Commentary (Tilaka) of Rāma. Fourth Revised Edition. Edited by Wāsudev Laxmaṇ Śāstrī Paṇśīkar. Bombay: Nirṇaya-sagar Press, 1930.

The Ristasamuccaya of Durgadeva. Critically Edited with Exhaustive Introduction, English Translation, Sanskrit Chāyā, Notes, Appendix, Indices etc. by Dr. A.S. Gopani. [Singhi Jain Series 21]. Bombay: Bharatiya Vidya Bhavan, 1945.

Rājanighaṇṭu, see DhN.

Abhidhānaratnamālā (Ṣadrasanighantuh). Edited by Prof. Priyavrat Sharma. [Jaikrishnadas Ayurveda Series 14]. Varanasi - Delhi: Chaukhambha Orientalia, 1977.

Śāligrāmanighaṇtubhūṣaṇam arthāt bṛhannighaṇțuratnākarāntargatau saptamāṣtamabhāgau śrīmāthuravaiśyavaṃśodbhavamurādābādasthakavikulakumudakalānidhiśrīśāligrāmavaidyavaryaviracitau. Mumbaī: Śrīveńkateśvar Steam Press, 19231924.

see Aufrecht 1873 
Śārṅgadharasaṃitāā

Saundarananda

Schmidt 1980

Sensarma 1998

Shamasastry 1960

Sharma 1975a

Sharma 1975b

Sharma 1981

Sharma 1985

Sharma 1997

Shastri 1969

Si.

Simha 1989

Simpha - Siṃha 1969

Singh - Chunekar 1972
The Śārngadhara-samhitā by Pandit Śārngadharāchārya Son of Pandit Dāmodara. With the Commentary Aḍhamalla's Dīpikā and Kāśīrāma's Gūọhārtha-Dīpikā. Edited with Foot Notes by Paṇdit Paraśurāma Śāstrī Vidyāsāgar. Bombay: Nirṇayasāgar Press, 1931.

The Saundarananda of Aśvaghosa. Critically Edited and Translated with Notes by E.H. Johnston. London: Oxford University Press, 1928 (repr. Delhi etc.: Motilal Banarsidass, 1975).

Hanns-Peter Schmidt, The Sēnmurw: Of Birds and Dogs and Bats. Persica 9 (1980) 1-85.

Priyadarsan Sensarma, Ethnobiological Information in Kautilīya Arthaśāstra. Calcutta: Naya Prokash, 1998.

Kautilya's Arthaśāstra. Translated by the Late Dr. R. Shamasastry. With an Introductory Note by Dr. J.F. Fleet. Mysore: Mysore Printing and Publishing House, ${ }^{6} 1960$.

P.V. Sharma, Áyurved kā vaijñānik itihās (Scientific History of Ayurveda). [Jaikrishna Das Ayurveda Series 1]. Varanasi: Chaukhambha Orientalia, 1975.

Id., Botanical Observations of Bāṇa Bhaț̣a (7th cent. A.D.). In: Dr. V. Raghavan Felicitation Volume. Delhi etc.: Motilal Banarsidass, 1975, p. 369-382 (repr. in Dubey - Singh 2005, p. $583-595)$.

Id., Dravyagun-vijñān. Vol. V (Discussion on Drugs). [The V. Ayurveda Series 3]. Varanasi: Chaukhambha Bharati Academy, 1981.

Id., Cakradatta mem prayukt viśișt auṣadhiyāṃ. Sachitr Āyurved 38,4 (1985) 347-355 (repr. in Dubey - Singh 2005, p. 628$639)$.

Id., Dravyagunakosah. Dictionary of Ayurvedic Terms Relating to Names, Synonyms, Properties and Actions of Medicinal Plants (Sanskrit-Hindi-English). [Acharya Priyavrat Sharma Ayurveda Series 2]. Delhi: Chaukhambha Orientalia, 1997.

Ajay Mitra Shastri, India as Seen in the Brihatsamhita of Varāhamihira. Delhi etc.: Motilal Banarsidass, 1969.

Siddhisthāna

Avadheś Nārāyaṇ Siṃha, Kautilīya arthaśāstra mem vānaspatik̄ (ek vivecanātmak adhyayan). Varanasi: Vijayalakshmi Publications, 1989.

Rāmjīt Siṃha - Hakīm Dalj̄it Siṃha, Āyurvedīya viśvakośa [Hindī kā sarvapratham arthapradhān, sarvāṅgapūrṇa śabdakośa]. cauthā khaṇ̣ ( $k \bar{a}$ se girikān tak). Prayāg: Hindī Sāhitya Sammelan, 1969.

Thakur Balwant Singh - K.C. Chunekar, Glossary of Vegetable Drugs in Brihattraȳi. [The Chowkhamba Sanskrit Studies 87]. Varanasi: The Chowkhamba Sanskrit Series Office, 1972. 
Singh - Singh 1981

Śivapurāṇa

Śivatattvaratnākara

ŚM

SN

Stache-Rosen 1977

Stein 1900

$\mathrm{Su}$.

Sū.

Subhāṣitaratnakoṣa

Sūtrakṛtānga

Syed 1990

Tantrasārasaṃgraha
R.S. Singh - A.N. Singh, On the Identity and EconomicoMedicinal Uses of Hastikarṇapalāśa (Leea macrophylla Roxb., Family: Ampelidaceae) as Evinced in the Ancient (Sanskrit) Texts and Traditions. Indian Journal of History of Science 16,2 (1981) 219-222.

Śrīśivamahāpurānam. Bombay: Śrīveñkațeśvar Press, 1954.

Śivatattvaratnākara of Basavarāja of Keladi. Vol. II. Edited by R. Rama Sastry. [Oriental Research Institute Publication 112]. Mysore: Oriental Research Institute, University of Mysore, 1969 .

Śrīmūlā, see Gaṇapati Śāstrī 1924-1925

Sodhala-nighantu (Nāmasañgraha and Gunasañgraha) of Vaidyācārya Sodhala. Edited by Priya Vrat Sharma. Baroda: Oriental Institute, 1978.

Valentina Stache-Rosen, Gandabherunda - Zur Tradition des doppelköpfigen Vogels in Südindien. In: Beiträge zur Indienforschung. Ernst Waldschmidt zum 80. Geburtstag gewidmet. [Veröffentlichungen des Museums für indische Kunst 4]. Berlin: Museum für indische Kunst, 1977, p. 489-510.

M.A. Stein (tr.), Kalhana's Rājataraingin̄i. A Chronicle of the Kings of Kaśmīr. Translated with an Introduction, Commentary and Appendices. 2 vols. Westminster: Archibald Constable and Company, 1900 (repr. Delhi etc.: Motilal Banarsidass, 1961).

The Suśrutasamhitā of Suśruta with the Nibandhasañgraha Com-

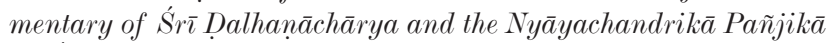
of Śr̄ Gayadāsāchārya on Nidānasthāna. Revised Third Edition, Edited from the Beginning to the 9th Adhyāya of Chikitsāsthāna by Vaidya Jādavji Trikamji Āchārya and the Rest by Nārāyaṇ Rām Āchārya "Kāvyatīrtha". Bombay: Nirṇaya Sāgar Press, 1938.

Sūtrasthāna

The Subhāṣitaratnakoșa Compiled by Vidyākara. Edited by D.D. Kosambi and V.V. Gokhale. Cambridge, Mass.: Harvard University Press, 1957.

see Jacobi 1895

Renate Syed, Die Flora Altindiens in Literatur und Kunst. Inaugural-Dissertation zur Erlangung des Doktorgrades der Philosophie an der Ludwig-Maximilians-Universität zu München, 1990.

Tantra Sāra Sañgraha (with Commentary). A Treatise Teaching Formulae and Rites for the Attainment of Health and Happiness and Even of Super-human Power of Nārāyaṇa (Tāntric) of Śivapuram. Edited Critically with Introduction in English and Sanskrit by Vaidyaratna Pandit Maduraiswami Aiyangar. [Madras Government Oriental Series 15]. Madras: Government Oriental Manuscripts Library, 1950. 
Tawney 1880

Thas 2004

Triṣaștiśalākāpuruṣacaritra

U.

Uttarādhyayana

Vaidya 1936

Vaidyaka-śabdasindhu

Vaidyarahasya

van Buitenen 1975

Vāsiṣthadharmasūtra

Vasudevahiṇdi

Viśvaprakāśa

VS

Watt 1885-1893

Wealth of India ${ }^{1}$
The Ocean of Story Being C.H. Tawney's Translation of Somadeva's Kathā Sarit Sāgara (or Ocean of Streams of Story). Now Edited with Introduction, Fresh Explanatory Notes and Terminal Essay by N.M. Penzer. 10 vols. Delhi etc.: Motilal Banarsidass, 1968 (orig. publ. 1924-1928).

J. Joseph Thas (ed.), Fourth National Conference on Siddha Medicine for All Ages, Thoothukudi, 11-12 December, 2004. Souvenir cum Scientific Abstracts. Tirunelveli: Friends of Siddha Medicine, 2004.

see Johnson 1962

Uttarasthāna

see Jacobi 1895

K.M. Vaidya, The Ashtanga Hridaya Kosha with the Hridaya Prakasha (A Critical and Explanatory Commentary). Trichur: The Mangalodayam Press, 1936.

see Gupta 1983

Vaidya Rahasya of Bhishagvara Vidyapati with 'Madhuri' Hindi Commentary by Dr. Indradev Tripathi. [Krishnadas Ayurveda Series 60]. Varanasi: Krishnadas Academy, 2000.

J.A.B. van Buitenen, The Mahābhārata. 2. The Book of the Assembly Hall; 3. The Book of the Forest. Chicago - London: The University of Chicago Press, 1975.

see Olivelle 1999

The Vasudevahindi. An Authentic Jain Version of the Bṛhatkathā, with Selected Translations Compared to the Bṛhatkathāślokasangraha, Kathāsaritsāgara, Bṛhatkathāmañjarī and Some Important Jaina Works, Including the Unpublished Majjhimakhanda and with Extensive Notes, Introduction and Appendices, by Dr. Jagdishchandra Jain. [Lalbhai Dalpatbhai Series 59]. Ahmedabad: L.D. Institute of Indology, 1977.

Viśvaprakāśa of Śr̄̄ Maheśvara Sūri. Edited by Śrī Sīlaskandha Sthavira and Śrī Ratnagopala Bhatta. [Chowkhamba Sanskrit Series 37]. Varanasi: Chaukhamba Amarabharati Prakashan, ${ }^{2} 1983$.

Viṣnusmrti with the Commentary Keśavavaijayanti of Nandapandita. Edited by Pandit V. Krishnamacharya. 2 vols. [The Adyar Library Series 93]. Adyar, Madras: The Adyar Library and Research Centre, 1964.

George Watt, A Dictionary of the Economic Products of India. Volume I: Abaca to Buxus. Volume II: Cabbage to Cyperus. Volume VI, Part III: Silk to Tea. Calcutta: Superintendent of Government Printing, 1885, 1889, 1893 (repr. Delhi: Cosmo Publications, 1972).

Wealth of India. A Dictionary of Indian Raw Materials and 
Wealth of India ${ }^{2}$

Weber 1858

Whitney 1905

Winternitz 1920

Yādavaśarman $1950-1951$

Yogaratnākara
Industrial Products - Raw Materials. Vols. I-XI. New Delhi: Council of Scientific and Industrial Research, 1948-1976.

Wealth of India. A Dictionary of Indian Raw Materials and Industrial Products - Raw Materials. Vol. 1: A (revised); Vol. 2: $B$ (revised); Vol. 3: $C a-C i$ (revised). New Delhi: Council of Scientific and Industrial Research, 1985, 1988, 1992.

A. Weber, Über das Çatruñjaya Mâhâtmyam. Ein Beitrag zur Geschichte der Jaina. [Abhandlungen der Deutschen Morgenländischen Gesellschaft 1,4]. Leipzig: F.A. Brockhaus 1858.

William Dwight Whitney, Atharva-Veda-Samhitā. Translated With a Critical and Exegetical Commentary. 2 vols. [Harvard Oriental Series 7-8]. Cambridge, Mass.: Harvard University, 1905 (repr. Delhi etc.: Motilal Banarsidass, 1962).

Moriz Winternitz, Geschichte der indischen Litteratur. Band 2: Die buddhistische Litteratur und die heiligen Texte der Jainas. Leipzig: C.F. Amelangs Verlag, 1920 (repr. Stuttgart: K.F. Koehler Verlag, 1968).

Yādavaśarman, Dravyagunavijñānam. uttarārdhasya auṣadhadravyavijñānīyo nāma dvitīyạ̣ khaṇḍạ. Bambaī: Nirṇayasāgar Press, 1950-1951.

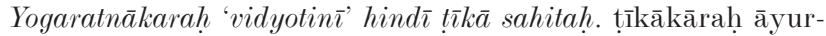
vedācārya vaidya śrī lakṣmīpati śāstrī. sampādakah bhiṣagratna śrī brahmaśankar śāstrī. [Kāsś̄-Samskrț-Granthamālā 160]. Banāras: Caukhambā Sạ̣skṛt Sīrij Āphis, 1955. 
